\title{
Effect of Microbial Phytase on Nutrient Availability and Growth of Juvenile Clarias gariepinus Fed Soyabean and Groundnut-based Diets
}

\author{
Akpoilih Benjamin Uzezi ${ }^{1^{*} \#}$, Ajani Emmanuel Kolawole ${ }^{2}$ \\ and Omitoyin Bamidele Oluwarotimi ${ }^{2}$ \\ ${ }^{1}$ Department of Fisheries, University of Port Harcourt, Nigeria. \\ ${ }^{2}$ Department of Aquaculture and Fisheries Management, University of Ibadan, Nigeria.
}

Authors' contributions

This work was carried out in collaboration among all authors. All authors read and approved the final manuscript.

Article Information

DOI: 10.9734/ARRB/2019/v31i430057

Editor(s):

(1) Dr. George Perry, Dean and Professor of Biology, University of Texas at San Antonio, USA.

Reviewers:

(1) Adesola A, Rhodes University, South Africa.

(2) ABA Mustapha, Tofail University, Morocco.

(3) Jorge Isaac Castro Bedriñana, National University of Central Peru, Peru.

(4) Shaimaa Selim, Helsinki University, Finland.

Complete Peer review History: http://www.sdiarticle3.com/review-history/26092

Original Research Article

Received 19 February 2016

Accepted 05 September 2016

Published 06 April 2019

\begin{abstract}
Several studies have shown the positive effect of phytase on phosphorus utilization by fish and animals, with the use of phytase sources determined for different fish species. Few studies have tested phytase response to different diets, which may affect nutrient availability for optimum growth due to differences in phytate location. The research, therefore, studied the effect of phytase to diets based on soya bean and groundnut meal for Clarias gariepinus on nutrient availability and growth. In trial 1, four groups of soya bean S1, S2, S3 and S4 replaced fish meal at $25 \%, 50 \%, 75 \%$ and $100 \%$ and supplemented with $250,500,750$ and $1000 \mathrm{FTU} / \mathrm{g}$ phytase, respectively. In trial 2, four groups of groundnut meal diet G1, G2, G3, G4, G5 and G6, were similarly supplemented with the same phytase levels used in experiment 1 . Fish meal control $(\mathrm{S} 0=\mathrm{G} 0)$ was not supplemented with phytase. Result showed that $250 \mathrm{FTU} / \mathrm{g}$ phytase showed the highest mean weight gain for both plants. In conclusion, the research has shown that the chemical nature of phytate, rather than its
\end{abstract}


concentration and location, may influence the utilization of phosphorus for optimum growth in the fish by supplementing $250 \mathrm{FTU} / \mathrm{g}$, with a range of available phosphorus requirement of between $0.75 \%\left(Y=0.363+4.155 X-2.772 X^{2}, R^{2}=0.759\right)$ and $0.80 \%\left(Y=0.307+3.303 X-2.059 X^{2}, R^{2}=\right.$ $0.210)$

Keywords: Phytase; plant proteins; nutrient availability; growth; Clarias gariepinus.

\section{INTRODUCTION}

Phytate has been reported to bind protein and amino acid through the binary protein-phytate complexes formed below the isoelectric point of protein $(\mathrm{pH}<5-6)[1,2]$. At low $\mathrm{pH}$, phytic acid interacts with $\alpha-\mathrm{NH} 2$ groups and with the side groups of basic amino acids, which include arginine, histidine, and lysine [2,3]. Phytate also binds with crystalline amino acids in the gut, and it has been suggested that the de novo formation of binary protein-phytate complexes in the gastrointestinal tract, which are refractory to pepsin activity, may be responsible for the reduction of amino acid digestibility [4] and hence reduces the effective utilization of amino acid in fish and animals [5]. Phytase has been variously used to improve amino acid utilization in animals $[2,6,7,8]$ through an improvement in phosphorus availability, which reported to range between $60 \%-80 \%$ by supplementing $500-1000 \mathrm{FTU} / \mathrm{g}$ [9]. Improvement in amino acid corresponds to improvement in growth [10]. The extent to which phytase generates improvements in protein digestibility in animal studies is variable and the topic remains controversial [1]. According to Selle and Ravindran [1], factors influencing response of nutrient availability to phytase include: differences between ingredient types, dietary levels of $\mathrm{Ca}$ and non-phytate-P, age of animal, the inherent digestibility of dietary amino acids, the sources and concentrations of phytate in the diet, and the inclusion level and type of added phytase. The positive effects of phytase on amino acid availability have been observed in several animal studies in low phosphorus and amino acid-deficient diets $[6,7,11,12,13,14]$. Huynh and Nugegoda [15] reported that inclusion of phytase and/ or amino acids did not improve amino acid profile of canola meal diet supplemented with limiting amino acid in Australian catfish (Tandanus tandanus), which showed no improvement in growth of the fish. Similarly, supplementation of phytase in amino acid-adequate diet of young chicks fed diet based on groundnut cake had no effect on growth [12].

Cao et al. [16] reported that Nile tilapia fed diet with and without phytase showed no difference in protein utilization, with a reduction in dietary methionine and lysine as the level of phytasepretreated diet increased. The phosphorus requirement of juvenile African catfish has been reported to range from $0.67 \%$ to $0.82 \%$ using inorganic phosphorus [16]. However, Van Weerd et al. [17] reported that the available phosphorus of juvenile Clarias gariepinus fed phytasesupplemented diet could be higher than $0.40 \%$; hence, the phosphorus requirement could still be higher than reported value. Moreover, matrix value of phytase supplementation, with particular reference to digestible protein, energy as well as lysine and methionine availability and the available phosphorus requirement by phytase supplementation of plant-based diets of African catfish has not been reported. Data on this aspect of phytase effect has been described severally for pigs and poultry (BASF and Quantum, personal communications). Nwanna et al. [18] reported an optimum growth requirement of 8000 FTU/g for juvenile Clarias gariepinus. In another study, the optimum level for growth was reported at $750 \mathrm{FTU} / \mathrm{g}$, with both studies evaluated using different phytase sources supplemented in soya bean. There is no report of the optimum level determined for different plant sources, with the aim of evaluating available phosphorus response for the fish. An evaluation of available phosphorus requirement would not only improve the nutritional need of the fish, which is mainly omnivorous in feeding habit, and hence, utilize plant proteins effectively [19], but would allow a least cost formulation on an available phosphorus basis, and reduce pollution from oversupply of phosphorus in meeting the phosphorus requirement of the fish resulting from phosphorus deficiency due to phytate [5]. Additionally, the use of phytase would allow for a quantification of an estimate of the lysine and methionine requirement of the fish, which could also be used in improving the nutritional value of catfish feed. Phytate in soya bean and groundnut meal are located differently [20,21], which could show varying response [12]. Hence, the research was carried out to evaluate amino acid profile, availability of nutrient and growth performance of juvenile Clarias gariepinus fed soya bean and groundnut meal based diets. 


\section{MATERIALS AND METHODS}

\subsection{Diet Preparation}

A growth and digestibility trial was carried out to assess the effect of phytase supplementation in roasted soya bean and groundnut meal-based diets of juvenile Clarias gariepinus. In both trials, about 15 and $20 \mathrm{~kg}$ of raw soya bean and groundnuts were purchased from a cereal and grain market in Ibadan, Oyo State, Nigeria. Soya bean and groundnut seeds were subjected to dry heat treatment [22] with slight modifications [23] by roasting on a metal plate at $120^{\circ} \mathrm{C}$ for $30-45$ minutes. Roasted soybeans were grinded, sundried, and packed into plastic bags, and stored at ambient temperature prior to inclusion in the formulation of with other feeding stuff. Groundnut seeds were milled into meals and packed in a large sack having minute pore spaces, which allowed free flow of air and moisture to allow for easy passage of oil. The bag was squeezed (oil-pressed) several times before being stored in a cool, dried place. The bag containing milled groundnut was placed on a plain surface, with heavy wooden blocks placed on it to further reduce the level of oil, which was allowed to drain for about 3-4 days before mixing with other ingredients feedstuffs for the fish [24]. All diets were formulated using Pearson's method of diet formulation [25] without added inorganic phosphorus and amino acid supplements to optimize phytate hydrolysis in the diets. In trial one, five graded levels of soya bean were formulated to replace fish meal at 0\% (S0), $25 \%$ (S1), 50\% (S2), $75 \%$ and $100 \%$ (S4), using similar procedure by [26]. The phytate contents of the respective diets were $0.40 \%, 0.52 \%$, $0.57 \%, 0.43 \%$ and $0.40 \%$, respectively. Another four basal diets (S1, S2, S3 and S4) were formulated with similar composition and supplemented with post-pelleting liquid phytase (Natuphos 5000L, BASF Corporation, Ludwigshafen, Germany), which was produced from submerged fermentation of Aspergillus niger strain FTU-11 (CBS 491.94), a genetically modified derivative of a parental strain GAM-53, at $250 \mathrm{FTU} / \mathrm{g}$ (P1), $500 \mathrm{FTU} / \mathrm{g}$ (P2), $750 \mathrm{FTU} / \mathrm{g}$ (P3) and $1000 \mathrm{FTU} / \mathrm{g}$ (P4). One FTU (phytase unit) is defined as the amount of phytase that liberates $1 \mu \mathrm{mol}$ of inorganic phosphorus from $0.0051 \mathrm{~mol} / \mathrm{L}$ of sodium phytate per minute at $\mathrm{pH}$ 5.5 and $37^{\circ} \mathrm{C}$ [8]. In trial two, similar levels of phytase were supplemented in increasing levels of roasted and oil-pressed groundnut meal diet at 10\% (G1), 20\% (G2), 30\% (G3), 40\% (G4), 50\% (G5) and $60 \%$ (G6), with basal phytate levels of $0.25 \%, 0.58 \%, 0.56 \%, 0.42 \%, 0.45 \%$ and $0.23 \%$.
All basal diets contained $0.20 \%$ calcium. S0 served as control without dietary phytase, and used to compare growth for both diets. Chromic oxide was added at $0.50 \%$ [27] for nutrient digestibility. Prior to phytase supplementation in both trials, each formulated diets was mixed using a large bowl with clean cold water and cold-pelleted using a sieve of mesh size $2 \mathrm{~mm}$ to produce a noddle-like strand of feed. Pelleted feeds were sun-dried and packed air-tight polythene bags before use. The control diet G0 was similar to S0 (fish meal) and was also included to compare growth performance. The proximate compositions of feed ingredients (Table 1) and gross composition of experimental diets (Tables 3 and 4 ) a below. Chemical analysis of phytate, phytase activity, proximate, and amino acids were done according to standard methods.

\subsection{Experimental Fish}

A total of 3978 Clarias gariepinus fish of average weight $4.5 \pm 0.2 \mathrm{~g}$ was procured from Jotmot Farms Alakia, in Egbeda LGA of Oyo State, Nigeria. In trial 1, A total of 1638 African sharptooth catfish of mean weight $4.5 \pm 0.2 \mathrm{~g}$ were acclimated to laboratory conditions for 3 weeks with water temperature, $\mathrm{pH}$ and oxygen maintained at optimum range between $25^{\circ} \mathrm{C}$ $32^{\circ} \mathrm{C}, 7.40-7.45,4.80-5.0 \mathrm{mg} / \mathrm{l}$. Water was sourced from a borehole through an overhead tank with a pipe, which supplied clean water to the Aquaculture and Fisheries Management laboratory, University of Ibadan, Oyo State, Nigeria. Healthy fish for the experiments were sourced from private fish farm in Ibadan, Nigeria. All phytase-supplemented diets were fed at $3 \%$ body weight to fish of mean weight of $11.55 \pm$ $0.20 \mathrm{~g}$, which were stocked in triplicate groups at 26 fish per tank $(0.43 \mathrm{~m} \times 0.25 \mathrm{~m} \times 0.265 \mathrm{~m})$. In trial 2, after acclimation (3 weeks), 2340 juvenile $\mathrm{C}$ gariepinus fish of mean weight $11.55 \pm 0.20 \mathrm{~g}$ were randomly allocated to the phytasesupplemented groundnut diet. Fish were stocked at 26 fish per tank in triplicate and fed the phytase treated diet at 3\% body weight for the first four weeks, which was reduced to $1.5 \%$ until the end of the experiment, which lasted for 84 days. All fish were weighed biweekly throughout the experiments using an electronic compact balance S. Mettler scale correct to $0.01 \mathrm{~g}$ (Model: $\mathrm{K}-\mathrm{BH}$ ). About $80 \%$ of water in experimental tanks were renewed every day, using a static renewal method, and water quality monitored for all treatment tanks at the end of each experiment, which lasted for 84 days. 
Table 1. Proximate composition of feed ingredients

\begin{tabular}{llllllll}
\hline Ingredient & $\begin{array}{l}\text { Crude } \\
\text { protein (\%) }\end{array}$ & Fat (\%) & Ash (\%) & Fibre (\%) & $\begin{array}{l}\text { Moisture } \\
\text { (\%) }\end{array}$ & CHO (\%) & $\begin{array}{l}\text { Energy } \\
\text { (kcal/100 g) }\end{array}$ \\
\hline $\begin{array}{l}\text { Fish meal } \\
\text { SBM }\end{array}$ & 66.46 & 5.32 & 4.33 & 0.69 & 9.28 & 13.79 & 380 \\
$\begin{array}{l}\text { (Full-fat) } \\
\text { SBM }\end{array}$ & 42.93 & 18.41 & 5.34 & 7.86 & 8.47 & 17.00 & 420 \\
$\begin{array}{l}\text { (Raw) } \\
\begin{array}{l}\text { Groundnut } \\
\text { (roasted) }\end{array}\end{array}$ & 35.5 & 19.48 & 5.06 & 5.59 & 12.13 & 22.25 & 420 \\
$\begin{array}{l}\text { Groundnut } \\
\text { (raw) }\end{array}$ & 25.13 & 45.03 & 7.86 & 4.45 & 4.12 & 2.17 & 564 \\
Maize & 10.24 & 50.61 & 6.65 & 8.47 & 5.18 & 8.47 & 574 \\
\hline
\end{tabular}

Table 2. Gross composition of roasted, full-fat soyabean-basal diets for juvenile Clarias gariepinus

\begin{tabular}{llllll}
\hline Ingredient & $\mathbf{S 0}(\mathbf{0} \%)$ & $\mathbf{S 1}(\mathbf{2 5} \%)$ & $\mathbf{S 2}(\mathbf{5 0} \%)$ & $\mathbf{S 3}(\mathbf{7 5} \%)$ & $\mathbf{S 4}(\mathbf{1 0 0} \mathbf{)})$ \\
\hline Fish meal & 54.29 & 45.38 & 34.16 & 19.62 & - \\
Soyabean meal (full fat) & - & 15.13 & 34.16 & 58.85 & 92.15 \\
Maize & 41.71 & 35.49 & 27.68 & 17.53 & 3.85 \\
Vit Min Mix\# & 0.50 & 0.50 & 0.50 & 0.50 & 0.50 \\
Fish oil & 1.00 & 1.00 & 1.00 & 1.00 & 1.00 \\
CaCO3 & 0.50 & 0.50 & 0.50 & 0.50 & 0.50 \\
Salt & 0.50 & 0.50 & 0.50 & 0.50 & 0.50 \\
Chromic oxide & 0.50 & 0.50 & 0.50 & 0.50 & 0.50 \\
Cellulose* & 0.20 & 0.20 & 0.20 & 0.20 & 0.20 \\
Starch & 0.80 & 0.80 & 0.80 & 0.80 & 0.80 \\
\hline
\end{tabular}

\# Micro mineral mix contains per kilogram: Vit A (20, $000 \mathrm{IU})$, Vit. D3 (5, $000 \mathrm{IU})$, Vit. E (300 mg), Vit K3 (10 mg), Vit B1 (20 mg), Vit. B2 (25 mg), Vit. C (300 mg), Niacin (120 mg), Ca. Pantothenate (60 mg), Vit B6 (10 mg), Vit B12 (0.05), Folic acid (5 mg), Biotin (1 mg), Choline chloride (5 mg), Inositol (50 mg), Manganese (30 mg), Iron (35 mg), Zinc (45 mg), Copper (3 mg), lodine (5 mg), Cobalt (2 mg), Lysine (85 mg), Selenium (0.15mg), Antioxidant (80 mg), Methionine (100mg). * as carboxymethyl cellulose

Table 3. Gross composition of roasted, oil-pressed groundnut meal-basal diets for juvenile Clarias gariepinus

\begin{tabular}{|c|c|c|c|c|c|c|c|}
\hline Ingredient & G0 (0\%) & G1 (10\%) & G2 (20\%) & G3 (30\%) & G4 (40\%) & G5 (50\%) & G6 (60\%) \\
\hline $\begin{array}{l}\text { Fish meal } \\
(66.46 \%)\end{array}$ & 54.29 & 51.19 & 48.22 & 44.87 & 41.07 & 36.70 & 31.66 \\
\hline $\begin{array}{l}\text { Groundnut } \\
\text { meal } \\
(36.37 \%)\end{array}$ & - & 5.67 & 12.06 & 19.23 & 27.38 & 36.70 & 47.49 \\
\hline $\begin{array}{l}\text { Maize } \\
(10.24 \%)\end{array}$ & 41.71 & 39.14 & 35.72 & 31.90 & 27.55 & 22.60 & 16.85 \\
\hline Vit Min Mix\# & 0.50 & 0.50 & 0.50 & 0.50 & 0.50 & 0.50 & 0.50 \\
\hline Fish oil & 1.00 & 1.00 & 1.00 & 1.00 & 1.00 & 1.00 & 1.00 \\
\hline $\mathrm{CaCO} 3$ & 0.50 & 0.50 & 0.50 & 0.50 & 0.50 & 0.50 & 0.50 \\
\hline Salt & 0.50 & 0.50 & 0.50 & 0.50 & 0.50 & 0.50 & 0.50 \\
\hline $\begin{array}{l}\text { Chromic } \\
\text { oxide }\end{array}$ & 0.50 & 0.50 & 0.50 & 0.50 & 0.50 & 0.50 & 0.50 \\
\hline Cellulose* & 0.20 & 0.20 & 0.20 & 0.20 & 0.20 & 0.20 & 0.20 \\
\hline Starch & 0.80 & 0.80 & 0.80 & 0.80 & 0.80 & 0.80 & 0.80 \\
\hline
\end{tabular}




\subsection{Proximate and Chemical Analysis}

Feed samples per diet were analysed for proximate and mineral composition (Analytical Lab., International Institute of Tropical Agriculture, Moniya, Ibadan, Nigeria); phytate and amino acid profile (Multi Environmental Management Consultants Limited, Ikorodu, Lagos, Nigeria); while phytase activity was performed at the analytical lab., BASF SE, Lampertheim, Germany. Sample of feeds were analyzed for phosphorus, calcium, sodium, copper, and manganese and determined using flame atomic absorption spectrophotometer model Buck 205, Buck Scientific, USA. Phosphorus was determined spectrophotometrically by molybdovanadate method [28]. Proximate composition of the diets were determined by AOAC [29]. Phytate was measured according to method used in previous work by Akpoilih et al. [30]. The sample was extracted with $0.2 \mathrm{~N} \mathrm{HCl}$. Test tube containing $0.50 \mathrm{ml}$ of extract was sealed with a ground glass stopper. A tube containing 1 millilitre of frric solution was heated in a boiling water bath for 30 minutes. Care was taken to ensure that for the first 5 minutes, the tube remained well stoppered. After cooling in ice water for 15 minutes, the tube was allowed to adjust to room temperature. Once the tube reached room temperature, the content of the tube was mixed and centrifuged for 30 minutes at $3000 \mathrm{~g} .1 \mathrm{ml}$ of the supernatant was transferred to another test tube and $1.5 \mathrm{ml}$ of 2 , 2'- Bipyridine solution added. The absorbance was measured at $519 \mathrm{~nm}$ against distilled water. Phytase activity in feed samples were determined (Analytical Lab., BASF SE, Lampertheim, Germany) by methods of [31]. About $100 \mathrm{~g}$ feed was milled to a particle size less than $0.5 \mathrm{~mm}$. Two $5.0 \mathrm{~g}$ portions of each sample of feed was weighed with an accuracy of $10 \mathrm{mg}$ into an Erlenmeyer flask. $50.00 \mathrm{ml}$ acetate buffer was metered by a dispenser into each sample, and the mixture was then stirred on a magnetic stirrer for $60 \mathrm{~min}$. The stirring was followed by decantation into $10 \mathrm{ml}$ centrifuge tubes and centrifugation at $4000 \mathrm{rpm}$ (equivalent to about $2500 \mathrm{~g}$ ) for 20 minutes. The centrifugate was then diluted with buffer using the dilutor to a content of about $0.02 \mathrm{FTU} / \mathrm{ml}$. $2.00 \mathrm{ml}$ of each of the two solutions was pipetted as sample and sample blank into a $10 \mathrm{ml}$ centrifuge tube. For the blank, $2.00 \mathrm{ml}$ portions of acetate buffer were pipetted into two $10 \mathrm{ml}$ centrifuge tubes. One centrifuge tube was incubated, and the other centrifuge tube was treated in analogy to the blanks as enzyme standard. The centrifuge tubes with the enzyme, sample blank and control solutions were each placed at a defined time interval (e.g. every $10 \mathrm{sec}$ ) in a water bath at $37.0+/-0.1^{\circ} \mathrm{C}$ and equilibrated for exactly $5 \mathrm{~min}$. Then, at the same time intervals (every $10 \mathrm{sec}$ ), $4.00 \mathrm{ml}$ sodium phytate solution (equilibrated at $37.0+/-0.1^{\circ} \mathrm{C}$ ) was added by a dispenser and mixed. After incubation for exactly $60 \mathrm{~min}$, the reaction was stopped, again at the same time intervals (every $10 \mathrm{sec}$ ), with $4.00 \mathrm{ml}$ stop reagent and mixed to produce a colored complex with the phosphate formed. After waiting for at least $10 \mathrm{~min}$, the solutions were centrifuged at $4000 \mathrm{rpm}$ (equivalent to about $2500 \mathrm{~g}$ ) for 20 minutes and then the absorbance at a wavelength of $415 \mathrm{~nm}$ was measured in a spectrophotometer. The enzyme phytase liberates inorganic phosphate from the substrate sodium phytate during incubation and the intensity of the yellow color of the vanadomolybdophosphorus complex is a measure of the amount of phosphate liberated.

The Amino Acid profile of feed $(n=2)$ was determined using methods described by Benitez [32], which involved defatting, determination of nitrogen, hydrolysis, evaporation and analysis.

\subsection{Growth Evaluation}

Growth performance was monitored biweekly with the following parameters measure. Mean weigh gain was determined from the difference between mean final weight and initial weight [33]. Daily weight gain was derived from dividing mean weight gain by period of feeding [34]. Feed Conversion Ratio (FCR) was estimated from the ratio of feed Intake and fish weight gain at the end of feeding [35]. Specific Growth Rate was determined from In (W2-W1)/ (t2-t1), where W2 and $W 1$ are weights on day $t 2$ and $t 1$, respectively [36]. Survival rate was determined from initial number of fish -mortality/ initial number of fish X 100 [37].

\subsection{Digestibility Studies}

The indirect method of determination of digestibility was used in this experiment with the addition of $0.5 \%$ chromic oxide as indigestible marker [28]. During the feeding experiment and two (2) weeks before the end of each experiment, faecal collection was done as follows. After feeding the fish for a second time each day $(18: 00 \mathrm{~h})$, faeces was drained out along with the water into a plastic containers. Water was gently drained out of the containers 
and faces collected using filter paper. Based on the maximum duration of activity of 2 hours of phytase, that is the interval between ingestion of feed and $80 \%$ of stomach evacuation, and an assumed cessation of phytase activity in the intestine [18], faeces were collected from each of the tanks 2-3 hours after each feeding. Faecal samples collected from all tanks were freezedried at $-20^{\circ} \mathrm{C}$ [38]. After freeze drying, faeces were analyzed $(n=3)$ for chromic oxide [30], protein [30], lipid [30], energy (Model 6200 microprocessor-controlled isoperibol oxygen bomb calorimeter) and phosphorus [30]. Apparent digestibility coefficient (ADC) was calculated for protein, energy, lipid, and phosphorus using the formula:

ADC nutrient $=100-100[\% \mathrm{Cr} 2 \mathrm{O} 3$ diet $/ \%$ $\mathrm{Cr} 2 \mathrm{O} 3$ faeces $X$ Nutrient faeces / Nutrient diet)]. Digestible nutrients were determined by multiplying digestibility values by dietary nutrients [18].

\subsection{Statistical Analysis}

Interactions between phytase and diets based on soya bean and groundnut meal were determined for mineral, amino acid profile, growth and nutrient digestibility using factorial analysis. Tukey HSD test of comparison was used to detect mean differences between mean pair for amino acid, mineral, growth and nutrient digestibility. Quadratic regression determined optimum available phosphorus level. All data were presented as means \pm S.D with a significant level of $\mathrm{P}=0.05$.

\section{RESULTS}

\subsection{Nutrient Digestibility}

The effects of experimental diets and phytase on proximate composition are presented in Table 4 and 5 . In full fat soya bean, significant interaction was observed for crude protein, energy, fat and protein digestibility $(P<0.05)$. Digestibility values for crude protein increased significantly with phytase supplementation, with the highest value recorded for $1000 \mathrm{FTU} / \mathrm{g}$ (Table 6). Energy digestibility decreased significantly for fish for all diets with phytase addition $(\mathrm{P}<0.05)$ compared to diets without phytase. Phytase at 250 FTU/g showed the highest fat digestibility compared to other diets, including control $(P<0.05)$. Increasing substitution of fish meal with soya bean resulted in a decline in phosphorus digestibility $(P<0.05)$. However, phytase at $1000 \mathrm{FTU} / \mathrm{g}$ showed the highest phosphorus digestibility compared to
250, 500 and $750 \mathrm{FTU} / \mathrm{g}$. Phytase at $1000 \mathrm{FTU} / \mathrm{g}$ showed the lowest phytate phosphorus and highest available phosphorus compared with control, 250, 500 and 750 FTU/g (Table 7).

In diet based on groundnut meal, no interaction between phytase and groundnut meal was observed for energy, lipid and phosphorus digestibility $(P>0.05)$. However, phytase supplementation significantly improved crude protein, energy and lipid digestibility (Table 8 ). The highest crude protein digestibility was recorded for $500 \mathrm{FTU} / \mathrm{g}$, while $250 \mathrm{FTU} / \mathrm{g}$ showed the highest phosphorus digestibility compared to control, 500, 750 and $1000 \mathrm{FTU} / \mathrm{g}$ $(P>0.05)$. The lowest phytate phosphorus and highest available phosphorus were also recorded for $250 \mathrm{FTU} / \mathrm{g}$ compared to 500,750 and 1000 FTU/g (Table 9).

\subsection{Growth}

Growth performance of fish showed a significant reduction $(P<0.05)$ in mean weight gain, daily weight gain, feed conversion ratio, specific growth rate and protein efficiency ratio with increasing level of soya bean (Table 10) and groundnut meal (Table 11), regardless of phytase level. However, phytase addition significantly improved the parameters of growth for both diets, with the highest growth performance recorded for $250 \mathrm{FTU} / \mathrm{g}$ (Figs. 1, 2). Survival rate declined significantly, regardless of soya bean level $(P<0.05)$. However, in groundnut meal, there was no significant effect of phytase on fish survival, which was highest in $250 \mathrm{FTU} / \mathrm{g}$ $(P>0.05)$.

\section{DISCUSSION}

Research conducted by several studies have demonstrated improvements in growth performance following phytase supplementation of inadequate phosphorus diets may be consistent with enhanced protein availability [2]. Many studies have demonstrated that phytase supplementation makes the chelated phytatephosphorus available to fish [8], and increase phosphorus digestibility compared to diets without phytase [39]. Yu and Wang [9] found that in soybean meal based diet for Crucian carp (Carassius carassius), about $60 \%$ and $80 \%$ of phosphorus can be released from phytate by the addition of 500 and 1000 FTU/g phytase, respectively. This is in line with this study (Table 7), which showed that the higher available phosphorus in soya bean diet supplemented with 
$250 \mathrm{FTU} / \mathrm{g}(0.53 \%)$ compared to control $(0.47 \%)$ translates to an increase of $0.13 \%$ [40], which is $60 \%$ phosphorus availability [9]. Protein digestibility improved significantly in soya bean with the highest value observed with $1000 \mathrm{FTU} / \mathrm{g}$ phytase, suggesting that protein digestibility may benefit significantly from phytase in fish diet, regardless of dietary composition and fish species $[41,42,43]$. Hussain et al. [42] reported the highest protein digestibility with addition of $1000 \mathrm{FTU} / \mathrm{g}$ phytase to corn-gluten based diet of Labeo rohita fingerlings compared to control, 250, 500, 750, 1250 and $1500 \mathrm{FTU} / \mathrm{g}$ diet. Pham et al. [44] also reported that supplementation of 1000 FTU/g improved significantly protein digestibility in cotton seed and soya bean meal based diet of juvenile Olive flounder (Paralichthys olivaceus). Phytate-phosphorus is converted to available phosphorus by phytase which can be utilized directly by animals [45].

Improvement in fat digestibility with phytase (250 $\mathrm{FTU} / \mathrm{g}$ ) is indicative of the release of small amount of amino acids [46] that may lead to an overall growth improvement [5]. Phytate has been reported to negatively influence energy utilization in broilers [1]. Enhanced availability of amino acids would increase the utilization of energy derived from protein $[1,8]$ and improve growth performance [2]. In this study, however, improved growth of fish (Fig.1) and fat digestibility did not translate to an overall improvement in energy digestibility compared to groundnut meal. This is contrary to the report that the positive impact of phytase on energy utilization stems from an accumulation of increases in fat digestibility [47], which needs further investigation. The reduction in energy digestibility with phytase may be due to a reduced amino acid profile in soya bean, with only an improvement in lysine, threonine, cysteine and isoleucine (Table 12) compared to a much improved amino acid (histidine, arginine, threonine, cysteine, isoleucine, leucine, and phenylalanine) with phytase in groundnut meal (Table 13). Improvement of histidine and arginine in groundnut by phytase may suggest the participation of the essential amino acids in the formation of phytate-protein complex through their alpha amino groups [2,3]. Reduction in arginine in soya bean by phytase may explain reduced energy digestibility. The reduction in lysine and methionine profiles in groundnut meal, which are the first limiting in most plants for optimal growth of fish [48] may suggest the need for dietary supplementation of the essential amino acids in groundnut meal diets for optimal growth of fish in future research, however, interactions with phytase should be taken into consideration. The significant improvement of amino acids in groundnut meal by phytase may possibly explain higher growth performance of fish (Fig. 2) compared to fish fed soya bean (Fig.1). Additionally, a reduction in energy digestibility reflects reduction in arginine profile of soya bean diet with increasing phytase. Similar response pattern was observed in soya bean diet, regardless of phytase level, which showed an improvement in arginine and a corresponding improvement in energy digestibility. This findings confirm reports in literature on the role of arginine in energy metabolism $[48,49]$ and amino-induced increase in energy release by phytase [46]. Reduction in energy digestibility may also result from the reduction in lipase activity in phytase supplemented diets [50] and high dietary fat in in diet compared to an improved energy digestibility in phytase-supplemented diet based on solventextracted soya bean [51].

The significant reduction in phosphorus digestibility in soya bean meal may be due to the high levels of saturated fat in soya bean compared to a much higher levels of monounsaturated and polysaturated fatty acids than saturated fat in groundnut meal [52]. High fat has also been reported to inhibit phosphorus absorption [53,54]. The improvement in phosphorus digestibility in solvent-extracted soya bean with 500, 750 and $1000 \mathrm{FTU} / \mathrm{g}$ compared to a diet with no phytase [51] suggest that fat in soya bean may inhibit phosphorus absorption in roasted soya bean, which also showed slight increase in faecal phosphorus (Table 6). This was also reported in Clarias gariepinus fed phytase supplemented soya bean diet, in another study, which suggest slight increase in faecal phosphorus by phytase is possible [17]. However, the higher availability of phosphorus and growth improvement in roasted soya bean compared to solvent-extracted soya bean [51] may suggest the reabsorption of phosphorus from the kidney through the sodium transporters NaPilla,c and III due to a reduced intestinal absorption [55]. The increase in phosphorus digestibility in groundnut meal supplemented with $250 \mathrm{FTU} / \mathrm{g}$ compared to control, 500, 750 and $1000 \mathrm{FTU} / \mathrm{g}$ may be related to its high phytate contents compared to soya bean [5], which enhanced the magnitude amino acid response to phytase [1,56], resulting overall growth improvement. Reduction in phytate phosphorus in groundnut meal with phytase at $250 \mathrm{FTU} / \mathrm{g}$ compared to control, 500, 750 and $1000 \mathrm{FTU} / \mathrm{g}$ 
(Table 9) may explain improved phosphorus digestibility and reduction in faecal phosphorus (Table 8). Improvement in nutrient digestibility may also result from the high levels of digestible energy and polyunsaturated fatty acids in groundnut meal [57].

Improvement in growth performance (Fig. 1) of fish fed soya bean by phytase at $250 \mathrm{FTU} / \mathrm{g}$ could be due to increased available phosphorus by phytase (Table 7), which reflected the requirement for catfish [28]. Phytase at 250 FTU/g in soya bean also showed improved threonine and methionine compared to other phytase diets (Table 12). The lysine level in 250 FTU/g (5.14\%) is higher than the reported lysine requirement of catfish, $5.10 \%$ [28].The highest methionine content in $250 \mathrm{FTU} / \mathrm{g}$ diet $(2.14 \%)$ is, however, lower than the requirement for catfish, $2.30 \%$ [28]. This may be due to the lack of significant response of methionine to phytase [1], which showed a reduction in roasted groundnut meal diet (Table 12). Selle and Ravindran [1] reported that, methionine is less responsive amino acid to phytase compared to ther amino acids. Only few studies have seen positive responses in animals $[7,12]$. Others did not find any improvement by phytase [13]. Richie et al. [58] observed decreased methionine with increasing phytase in soya bean-based diet of Nile tilapia. Improvement in growth with phytase at $250 \mathrm{FTU} / \mathrm{g}$ could possibly be explained by a corresponding improvement in available phosphorus from phytate [46]. This is in line with the report by (Cao et al. [8] who reported that channel catfish fed the diets containing 250 FTU/g phytase showed higher growth performance compared to diet without phytase. Improved growth performance by phytase in fish diet have also be reported for juvenile Clarias gariepinus fed diet based on full fat soya bean [18]. Haghbayan and Mehrgan, [59] reported growth improvement in rainbow trout fed soya bean diet supplemented with enzyme complex. Although a possibly higher than $0.40 \%$ available phosphorus by phytase was reported [17], the highest growth achieved at $250 \mathrm{FTU} / \mathrm{g}$, with a corresponding available phosphorus of $0.53 \%$ compared to $0.54 \%$ recorded for $1000 \mathrm{FTU} / \mathrm{g}$, which recorded the lowest growth performance compared to control, 250, 500 and $750 \mathrm{FTU} / \mathrm{g}$ phytase, showed that the available phosphorus of $250 \mathrm{FTU} / \mathrm{g}(0.53 \%)$ and phosphorus of $0.81 \%$ may be required for optimum growth performance of juvenile C. gariepinus. Similarly, the high available phosphorus and phosphorus of $250 \mathrm{FTU} / \mathrm{g}(0.51 \%)$ supplemented in groundnut meal compared to 500,750 and $1000 \mathrm{FTU} / \mathrm{g}$ phytase (Table 9) may suggest requirement of the fish may not depend on plant source of protein, as the values of available phosphorus for both diets with $250 \mathrm{FTU} / \mathrm{g}$ values are almost similar. The available phosphorus requirement determined in this study may not be significantly different from that of walking catfish (Clarias leather) fed $0.55 \%$ available phosphorus based on growth data [60]. Quadratic regression of specific growth rate on phytase level showed an available phosphorus ranging from $0.75 \%(\mathrm{Y}=$ $\left.0.363+4.155 X-2.772 X^{2}, R^{2}=0.759\right)$ to $0.80 \%$ $\left(Y=0.307+3.303 X-2.059 X^{2}, R^{2}=0.210\right)$, which is line with the requirement of omnivorous fish species [20].

The average phosphorus of $250 \mathrm{FTU} / \mathrm{g}(0.86 \%)$ determined for both plants sources may suggest a higher value of phosphorus requirement for juvenile $\mathrm{C}$. gariepinus compared to an average value of $0.75 \%(0.67-0.82 \%)$ reported for the fish [16]. The improvement in mean weight gain observed in fish fed $250 \mathrm{FTU} / \mathrm{g}$ phytase in both plants may be due to increase in feed consumption and the release of nutrient from the phytase-mineral complex [61,62,63].The optimum growth performance at $250 \mathrm{FTU} / \mathrm{g}$, regardless of plant protein used may suggest that the location and concentration of phytate in different plants may not be as necessary as the chemical nature of phytate, feed processing, fish species, stomach $\mathrm{pH}$ and phytase dose [42]. The report of this study may be corroborated by similar observations of an optimum dose of 750 FTU/g for nutrient availability and growth of Labeo rohita fingerlings fed different diets based on cotton seed meal [43], Canola meal [64] and sunflower meal [63]. The optimum growth performance by supplementing $250 \mathrm{FTU} / \mathrm{g}$ in this study compared to $750 \mathrm{FTU} / \mathrm{g}$ in Labeo roriha [64] may be due to an enhanced phytate hydrolysis at low stomach $\mathrm{pH}$ of Clarias gariepinus [17] compared to stomachless fish species such as Labeo rohita and Cyprinus carpio [42]. This may be similar to that of Channel catfish, which showed optimum growth performance with $250 \mathrm{FTU} / \mathrm{g}$. Robinson et al. [65] also reported similar findings for the fish, which also corroborated the report that a minimum of $250 \mathrm{FTU} / \mathrm{g}$ phytase is required in the diet of most fish species [8]. However, the result of this study contradicts the report of an optimum phytase of $750 \mathrm{FTU} / \mathrm{g}$ phytase (Natuphos 5000) for Clarias gariepinus fed soya bean diet, which may be due to formulation of phytase and the use of wheat [18]. The activity of phytase in wheat is high 
enough to compromise optimum phytate hydrolysis [66]. In a similar study, which also showed a different optimum phytase level of $8000 \mathrm{FTU} / \mathrm{g}$ (Ronozyme 5000) reported for the fish, the difference in the outcome may be due differences in phytase source, which could differ in phytate hydrolysis and thus show varying response in terms of phosphorus availability and growth performance $[8,42]$. Specie differences in optimum phytase showed different dietary requirement of $500 \mathrm{FTU} / \mathrm{g}$ for Pangasius pangasius [67], $750 \mathrm{FTU} / \mathrm{g}$ for Labeo rohita $[43,65]$ and $1000 \mathrm{FTU} / \mathrm{g}$ for Nile tilapia [25]. The decline in growth performance with phytase at $1000 \mathrm{FTU} / \mathrm{g}$ compared to 250, 500 and 750 $\mathrm{FTU} / \mathrm{g}$ in groundnut meal may be due to the inability of phytase to efficiently release phosphorus and other minerals from zinc-phytate complex [5,68], which may be due, in part, to high dietary fibre (Table 1) and calcium/phosphorus ratio (Table 11), which may facilitate calcium-zinc complex [2,5], thereby making it less assessable to phytase [69], resulting in reduced phytase activity and available phosphorus for the diet. The low growth performance in the fish fed $1000 \mathrm{FTU} / \mathrm{g}$ compared to 250 and $500 \mathrm{FTU} / \mathrm{g}$ phytase was also reported Labeo rohita fingerlings fed sunflower meal [63] and in Pangasius pangasius fingerlings [67]. The reduction of growth performance in both diets as the inclusion of soya bean and groundnut increased (Figs.1,2) may be due to the low amino acid profile [70] and presence of antinutrients [60].

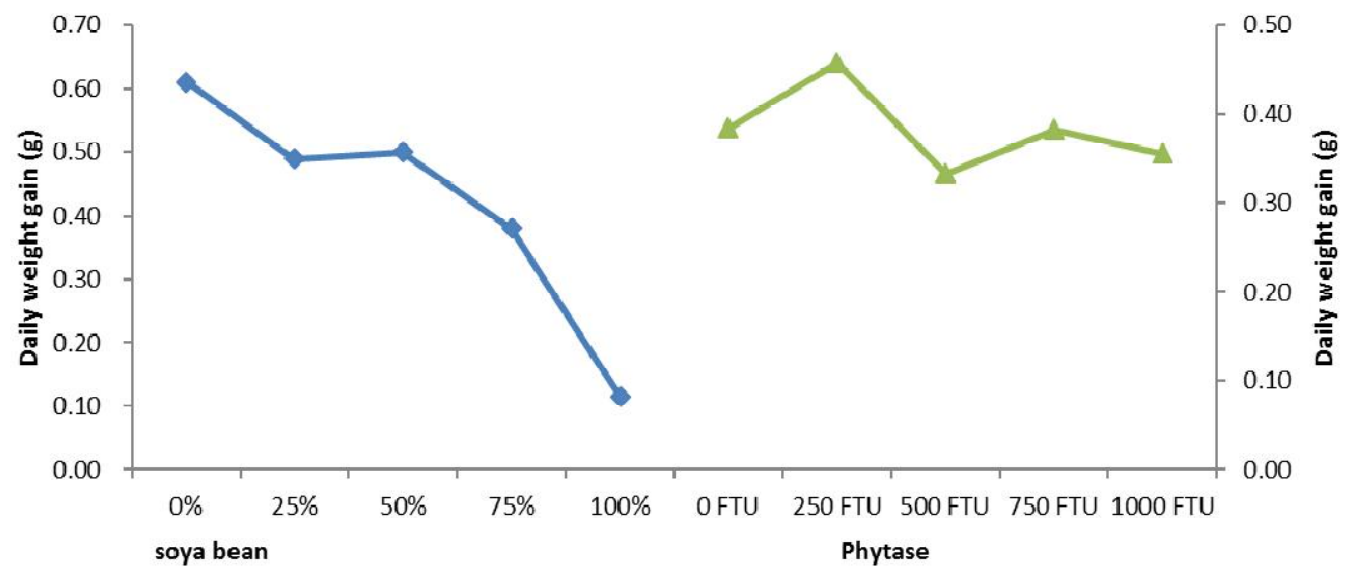

Fig. 1. Effect of soyabean and phytase on daily weight gai of juvenile Clarias gariepinus

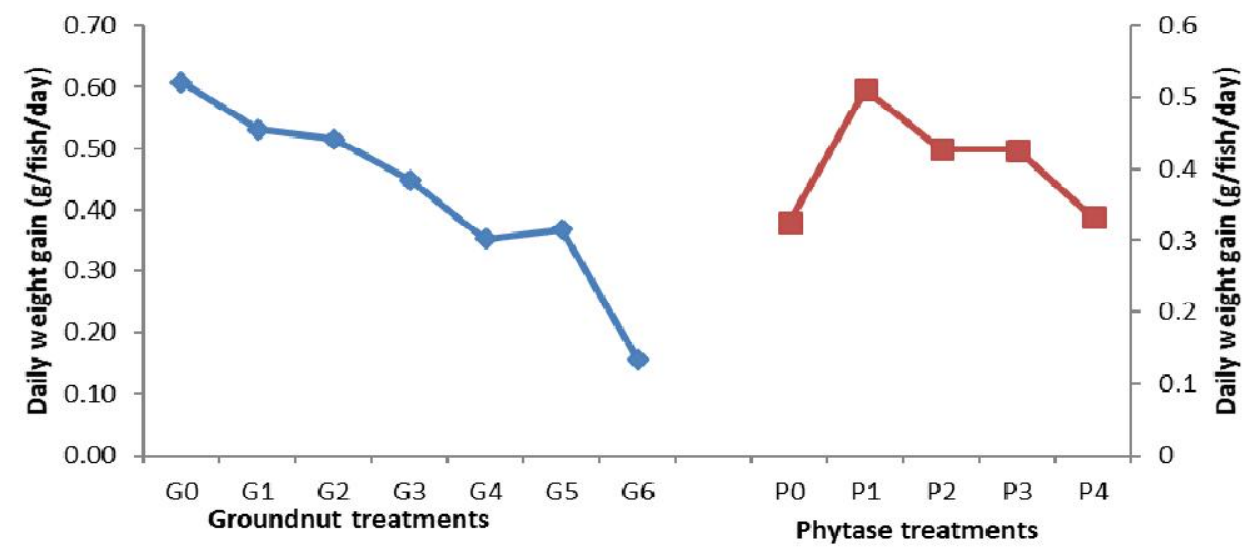

Fig. 2. Effect of groundnut meal and phytase on daily weight gain of juvenile Clarias gariepinus 
Table 4. Effect of soya bean (full fat) and phytase on proximate composition of juvenile Clarias gariepinus

\begin{tabular}{|c|c|c|c|c|c|c|c|}
\hline Sources of variation, $P$ value & Crude protein (\%) & Ash (\%) & Moisture (\%) & Fat (\%) & CF (\%) & $\begin{array}{l}\text { Energy } \\
\text { (Kcal/g) }\end{array}$ & NFE (\%) \\
\hline Phytase & 0.01 & 0.00 & 0.77 & 0.00 & 0.00 & 0.00 & 0.00 \\
\hline Soya bean & 0.000 & 0.00 & 0.00 & 0.00 & 0.00 & 0.00 & 0.00 \\
\hline Phytase* Soya bean & 0.001 & 0.00 & 0.00 & 0.00 & 0.00 & 0.00 & 0.00 \\
\hline Pooled SE & 0.48 & 0.00 & 0.00 & 0.00 & 0.00 & 0.00 & 0.01 \\
\hline \multicolumn{8}{|l|}{ Main effects } \\
\hline \multicolumn{8}{|l|}{ Phytase } \\
\hline PO & $42.30 \pm 1.99 d$ & $10.25 \pm 1.56 \mathrm{e}$ & $9.04 \pm 1.67 a$ & $15.74 \pm 5.34 a$ & $7.38 \pm 2.78 c$ & $4.30 \pm 0.30 b$ & $15.29 \pm 2.71 d$ \\
\hline P1 & $41.59 \pm 0.9 a$ & $8.71 \pm 1.59 a$ & $10.88 \pm 1.37 d$ & $20.09 \pm 7.27 e$ & $8.45 \pm 2.50 d$ & $4.40 \pm 0.02 d$ & $10.28 \pm 7.52 a$ \\
\hline $\mathrm{P} 2$ & $41.80 \pm 0.86 b$ & $9.86 \pm 2.38 d$ & $10.34 \pm 2.75 c$ & $15.93 \pm 7.25 b$ & $6.84 \pm 1.57 a$ & $4.40 \pm 0.02 c$ & $15.23 \pm 3.89 d$ \\
\hline P3 & $42.10 \pm 0.68 c$ & $8.83 \pm 0.18 b$ & $10.30 \pm 1.19 b$ & $17.73 \pm 4.23 c$ & $7.33 \pm 1.89 c$ & $4.30 \pm 0.02 b$ & $14.72 \pm 2.16 c$ \\
\hline P4 & $42.52 \pm 0.63 e$ & $9.62 \pm 2.16 c$ & $9.35 \pm 1.16 b$ & $17.87 \pm 4.44 d$ & $7.09 \pm 1.96 b$ & $4.20 \pm 0.01 \mathrm{a}$ & $13.55 \pm 5.51 b$ \\
\hline \multicolumn{8}{|l|}{ Soya bean } \\
\hline so & $45.75 \pm 0.01 e$ & $12.88 \pm 0.15 e$ & $10.83 \pm 0.04 e$ & $11.18 \pm 0.00 a$ & $3.92 \pm 0.11 a$ & $3.90 \pm 0.00 \mathrm{a}$ & $15.45 \pm 0.31 d$ \\
\hline S1 & $42.67 \pm 0.32 d$ & $11.13 \pm 0.85 d$ & $10.20 \pm 0.99 d$ & $12.64 \pm 4.69 b$ & $7.79 \pm 1.59 d$ & $4.20 \pm 0.00 b$ & $15.99 \pm 5.09 e$ \\
\hline S2 & $42.39 \pm 0.27 c$ & $10.18 \pm 1.00 \mathrm{c}$ & $10.63 \pm 1.98 c$ & $15.64 \pm 3.89 c$ & $5.95 \pm 1.52 b$ & $4.20 \pm 0.01 c$ & $15.24 \pm 4.01 \mathrm{c}$ \\
\hline S3 & $41.80 \pm 0.44 b$ & $9.14 \pm 0.25 b$ & $0.61 \pm 0.61 b$ & $18.15 \pm 2.90 d$ & $6.73 \pm 1.51 \mathrm{c}$ & $4.40 \pm 0.00 d$ & $14.57 \pm 3.84 b$ \\
\hline S4 & $40.72 \pm 0.59 a$ & $6.84 \pm 1.02 a$ & $8.33 \pm 2.40 \mathrm{a}$ & $24.79 \pm 1.70 \mathrm{e}$ & $9.19 \pm 1.36 \mathrm{e}$ & $4.60 \pm 0.00 \mathrm{e}$ & $9.42 \pm 4.42 \mathrm{a}$ \\
\hline
\end{tabular}

*Means with the same superscript in the same column are not significant $(P>0.05)$

Table 5. Effect of groundnut (roasted) and phytase on proximate composition of juvenile Clarias gariepinus

\begin{tabular}{|c|c|c|c|c|c|c|c|}
\hline Sources of variation, $P$ value & Crude protein (\%) & Fat (\%) & Ash (\%) & Moisture (\%) & $\begin{array}{ll}\begin{array}{l}\text { Crude } \\
\text { (\%) }\end{array} & \\
\end{array}$ & $\begin{array}{l}\text { Energy } \\
\text { (Kcal/g) }\end{array}$ & NFE (\%) \\
\hline Phytase & 0.01 & 0.00 & 0.00 & 0.00 & 0.00 & 0.00 & 0.00 \\
\hline Groundnut & 0.000 & 0.00 & 0.00 & 0.00 & 0.00 & 0.00 & 0.00 \\
\hline Phytase* Groundnut & 0.001 & 0.00 & 0.00 & 0.00 & 0.00 & 0.00 & 0.00 \\
\hline $\begin{array}{l}\text { Pooled SE } \\
\text { Main effects } \\
\text { Phytase }\end{array}$ & 0.48 & 0.00 & 0.00 & 0.00 & 0.00 & 0.00 & 0.00 \\
\hline $\mathrm{PO}$ & $42.89 \pm 2.05 d$ & $16.92 \pm 5.73 a$ & $9.70 \pm 2.53 \mathrm{e}$ & $7.32 \pm 2.81 \mathrm{a}$ & $6.36 \pm 1.81 a$ & $4.23 \pm 0.02 c$ & $16.81 \pm 4.80 \mathrm{e}$ \\
\hline $\mathrm{P} 1$ & $41.62 \pm 1.55 b$ & $18.71 \pm 5.56 c$ & $7.71 \pm 1.05 b$ & $7.99 \pm 0.90 \mathrm{e}$ & $7.71 \pm 1.50 b$ & $4.26 \pm 0.02 d$ & $16.50 \pm 3.20 c$ \\
\hline $\mathrm{P} 2$ & $41.67 \pm 1.69 c$ & $18.18 \pm 11.65 b$ & $7.58 \pm 1.69 a$ & $7.80 \pm 0.66 b$ & $8.13 \pm 1.83 c$ & $4.22 \pm 0.02 b$ & $16.64 \pm 7.00 \mathrm{~d}$ \\
\hline P3 & $41.60 \pm 1.55 a$ & $18.68 \pm 12.32 c$ & $8.47 \pm 1.46 \mathrm{~d}$ & $7.81 \pm 1.24 c$ & $8.51 \pm 0.89 d$ & $4.23 \pm 0.02 c$ & $14.93 \pm 6.44 b$ \\
\hline
\end{tabular}


Uzezi et al.; ARRB, 31(4): 1-21, 2019; Article no.ARRB. 26092

\begin{tabular}{|c|c|c|c|c|c|c|c|}
\hline Sources of variation, $P$ value & Crude protein (\%) & Fat (\%) & Ash (\%) & Moisture (\%) & $\begin{array}{ll}\begin{array}{l}\text { Crude } \\
(\%)\end{array} & \text { fibre } \\
\end{array}$ & $\begin{array}{l}\text { Energy } \\
\text { (Kcal/g) }\end{array}$ & NFE (\%) \\
\hline $\begin{array}{l}\text { P4 } \\
\text { Groundnut }\end{array}$ & $42.57 \pm 1.64 \mathrm{e}$ & $19.90 \pm 5.28 d$ & $8.40 \pm 0.86 c$ & $7.86 \pm 0.68 \mathrm{~d}$ & $8.95 \pm 1.53 e$ & $4.13 \pm 0.02 a$ & $12.32 \pm 4.96 a$ \\
\hline G0 & $44.75 \pm 0.01 \mathrm{f}$ & $10.83 \pm 0.04 a$ & $12.88 \pm 0.15 \mathrm{~g}$ & $11.18 \pm 0.00 a$ & $3.92 \pm 0.11 \mathrm{a}$ & $3.94 \pm 0.01 a$ & $16.45 \pm 0.31 \mathrm{de}$ \\
\hline G1 & $43.75 \pm 0.48 \mathrm{e}$ & $14.41 \pm 4.88 b$ & $8.53 \pm 1.45 \mathrm{e}$ & $9.04 \pm 0.75 b$ & $8.12 \pm 1.67 \mathrm{~cd}$ & $3.95 \pm 0.01 b$ & $16.15 \pm 6.75 c$ \\
\hline G2 & $42.53 \pm 0.33 d$ & $17.24 \pm 8.79 d$ & $9.14 \pm 0.42 f$ & $6.81 \pm 2.57 \mathrm{c}$ & $7.95 \pm 1.81 \mathrm{bc}$ & $4.05 \pm 0.01 \mathrm{c}$ & $16.33 \pm 8.16 \mathrm{~d}$ \\
\hline G3 & $41.91 \pm 0.48 c$ & $17.09 \pm 7.65 c$ & $8.01 \pm 0.95 c$ & $8.09 \pm 0.51 \mathrm{~d}$ & $8.27 \pm 1.63 \mathrm{~cd}$ & $4.16 \pm 0.01 d$ & $16.63 \pm 5.42 f$ \\
\hline G4 & $41.83 \pm 0.47 c$ & $20.78 \pm 3.14 f$ & $7.94 \pm 0.85 b$ & $7.62 \pm 0.76 \mathrm{e}$ & $8.60 \pm 1.77 d$ & $4.31 \pm 0.00 \mathrm{e}$ & $13.23 \pm 5.48 b$ \\
\hline G5 & $41.65 \pm 0.51 b$ & $19.79 \pm 5.40 \mathrm{e}$ & $8.45 \pm 2.87 d$ & $7.49 \pm 0.49$ & $7.42 \pm 1.73 b$ & $4.36 \pm 0.01 f$ & $15.20 \pm 5.15 d$ \\
\hline G6 & $40.98 \pm 0.46 a$ & $25.83 \pm 0.85 \mathrm{~g}$ & $7.53 \pm 1.82 a$ & $6.72 \pm 0.83$ & $7.43 \pm 1.31 \mathrm{bc}$ & $4.51 \pm 0.01 \mathrm{~g}$ & $11.41 \pm 2.57 a$ \\
\hline
\end{tabular}

Table 6. Effect of soya bean and phytase on nutrient digestibility of juvenile Clarias gariepinus

\begin{tabular}{|c|c|c|c|c|c|}
\hline Sources of variation, $P$ value & Crude protein (\%) & Energy (\%) & Fat (\%) & Phosphorus (\%) & Faecal phosphorus (\%) \\
\hline Phytase & 0.007 & 0.000 & 0.000 & 0.000 & 0.00 \\
\hline Soya bean & 0.002 & 0.011 & 0.003 & 0.002 & 0.011 \\
\hline Phytase* Soya bean & 0.003 & 0.003 & 0.001 & 0.012 & 0.005 \\
\hline $\begin{array}{l}\text { Pooled SE } \\
\text { Main effects }\end{array}$ & 0.003 & 0.003 & 0.003 & 0.072 & 0.003 \\
\hline \multicolumn{6}{|l|}{ Phytase } \\
\hline $\mathrm{PO}$ & $90.86 \pm 0.56 a$ & $86.71 \pm 0.16 a$ & $81.00 \pm 6.47 b$ & $83.21 \pm 7.07 \mathrm{~d}$ & $0.41 \pm 0.01 \mathrm{a}$ \\
\hline P1 & $92.16 \pm 0.14 b$ & $86.58 \pm 0.24 a b$ & $83.08 \pm 9.28 d$ & $78.08 \pm 9.05 b$ & $0.52 \pm 0.01 \mathrm{e}$ \\
\hline P2 & $92.46 \pm 0.26 c$ & $86.60 \pm 0.30 b$ & $76.63 \pm 10.31 a$ & $77.11 \pm 8.82 a$ & $0.51 \pm 0.01 d$ \\
\hline P3 & $92.73 \pm 0.12 d$ & $86.66 \pm 0.16 c$ & $82.98 \pm 4.10 c$ & $78.07 \pm 8.08 b$ & $0.50 \pm 0.01 \mathrm{c}$ \\
\hline P4 & $92.89 \pm 0.05 e$ & $86.56 \pm 0.02 a b$ & $81.51 \pm 3.36 b$ & $82.05 \pm 3.26 \mathrm{c}$ & $0.49 \pm 0.01 b$ \\
\hline \multicolumn{6}{|l|}{ Soya bean } \\
\hline so & $89.91 \pm 0.01 a$ & $86.51 \pm 0.01 a$ & $76.24 \pm 0.01 b$ & $89.91 \pm 0.01 \mathrm{e}$ & $0.42 \pm 0.00 a$ \\
\hline S1 & $92.09 \pm 7.60 \mathrm{~b}$ & $86.51 \pm 0.13 a$ & $73.81 \pm 8.98 a$ & $87.12 \pm 1.13 d$ & $0.49 \pm 0.05 d$ \\
\hline S2 & $92.19 \pm 0.68 c$ & $86.49 \pm 0.13 a$ & $80.73 \pm 4.76 c$ & $81.22 \pm 1.32 c$ & $0.49 \pm 0.04 d$ \\
\hline S3 & $92.30 \pm 0.66 d$ & $86.60 \pm 0.09 b$ & $83.00 \pm 3.56 d$ & $80.23 \pm 2.00 b$ & $0.48 \pm 0.05 c$ \\
\hline S4 & $92.49 \pm 0.59 \mathrm{e}$ & $86.87 \pm 0.17 c$ & $87.57 \pm 2.59 \mathrm{e}$ & $68.90 \pm 6.23 a$ & $0.48 \pm 0.04 b$ \\
\hline
\end{tabular}

${ }^{*}$ Means with the same superscript in the same column are not significant $(P>0.05)$ 
Table 7. Effect of soya bean and phytase on total phosphorus, phytate and available phosphorus

\begin{tabular}{llc}
\hline Sources of variation, P value & Total phosphorus (\%) & Phytate (\%) \\
\hline Phytase & 0.001 & 0.000 \\
Soya bean & 0.004 & 0.000 \\
Phytase* Soya bean & 0.012 & 0.000 \\
Pooled SE & 0.002 & 0.002 \\
Main effects & & 0.002 \\
Phytase & $0.93 \pm 0.33 \mathrm{c}$ & 0.003 \\
P0 & $0.81 \pm 0.28 \mathrm{~b}$ & 0.005 \\
P1 & $0.79 \pm 0.31 \mathrm{a}$ & $0.28 \pm 0.12 \mathrm{a}$ \\
P2 & $0.79 \pm 0.27 \mathrm{a}$ & $0.44 \pm 0.14 \mathrm{~b}$ \\
P3 & $0.81 \pm 0.30 \mathrm{~b}$ & $0.47 \pm 0.06 \mathrm{c}$ \\
P4 & & $0.27 \pm 0.11 \mathrm{a}$ \\
Soya bean & $1.31 \pm 0.01 \mathrm{e}$ & $0.47 \pm 0.31 \mathrm{c}$ \\
S0 & $1.18 \pm 0.03 \mathrm{~d}$ & $0.53 \pm 0.32 \mathrm{~d}$ \\
S1 & $0.87 \pm 0.09 \mathrm{e}$ & $0.35 \pm 0.19 \mathrm{~b}$ \\
S2 & $0.75 \pm 0.02 \mathrm{~b}$ & $0.32 \pm 0.25 \mathrm{a}$ \\
S3 & $0.42 \pm 0.02 \mathrm{a}$ & $0.54 \pm 0.36 \mathrm{~d}$ \\
S4 & & $0.40 \pm 0.02 \mathrm{~b}$ \\
& & \\
\end{tabular}

${ }^{*}$ Means with the same superscript in the same column are significant $(P>0.05)$

Table 8. Effect of phytase and groundnut meal on nutrient digestibility of juvenile Clarias gariepinus

\begin{tabular}{|c|c|c|c|c|c|}
\hline Sources of variation, $P$ value & Crude protein (\%) & Energy (\%) & Fat (\%) & Phosphorus (\%) & Faecal phosphorus (\%) \\
\hline Phytase & 0.007 & 0.000 & 0.000 & 0.346 & 0.243 \\
\hline Groundnut & 0.002 & 0.001 & 0.003 & 0.492 & 0.575 \\
\hline Phytase* Groundnut & 0.003 & 0.095 & 0.183 & 0.446 & 0.552 \\
\hline Pooled SE & 0.001 & 0.001 & 0.001 & 0.807 & 0.000 \\
\hline \multicolumn{6}{|l|}{ Main effects } \\
\hline \multicolumn{6}{|l|}{ Phytase } \\
\hline $\mathrm{PO}$ & $91.29 \pm 0.16 a$ & $87.08 \pm 0.15 a$ & $83.56 \pm 5.37 a$ & $86.25 \pm 6.07 a$ & $0.53 \pm 0.01 \mathrm{a}$ \\
\hline $\mathrm{P} 1$ & $91.83 \pm 0.14 d$ & $87.72 \pm 0.21 \mathrm{c}$ & $85.96 \pm 9.28 b$ & $90.24 \pm 7.05 a$ & $0.29 \pm 0.01 a$ \\
\hline P2 & $91.84 \pm 0.26 \mathrm{e}$ & $87.74 \pm 0.30 d$ & $88.27 \pm 4.31 \mathrm{e}$ & $90.20 \pm 6.82 a$ & $0.29 \pm 0.01 \mathrm{a}$ \\
\hline P3 & $91.73 \pm 0.12 c$ & $87.56 \pm 0.16 b$ & $87.09 \pm 4.13 d$ & $90.17 \pm 8.06 a$ & $0.29 \pm 0.01 a$ \\
\hline $\mathrm{P} 4$ & $91.71 \pm 0.05 b$ & $87.56 \pm 0.02 b$ & $86.18 \pm 3.31 \mathrm{c}$ & $89.18 \pm 3.26 a$ & $0.29 \pm 0.01 a$ \\
\hline Groundnut & & & & & \\
\hline
\end{tabular}


Uzezi et al.; ARRB, 31(4): 1-21, 2019; Article no.ARRB. 26092

\begin{tabular}{|c|c|c|c|c|c|}
\hline Sources of variation, $P$ value & Crude protein (\%) & Energy (\%) & Fat (\%) & Phosphorus (\%) & Faecal phosphorus (\%) \\
\hline G0 & $89.91 \pm 0.01 a$ & $86.51 \pm 0.01 \mathrm{a}$ & $76.24 \pm 0.01 \mathrm{a}$ & $89.91 \pm 0.01 a$ & $0.42 \pm 0.00 a$ \\
\hline G1 & $91.52 \pm 0.60 c$ & $87.45 \pm 0.13 c$ & $80.22 \pm 4.98 b$ & $90.64 \pm 1.13 a$ & $0.30 \pm 0.05 a$ \\
\hline G2 & $91.51 \pm 0.63 b$ & $87.27 \pm 0.13 b$ & $82.74 \pm 4.76 c$ & $85.50 \pm 1.32 a$ & $0.35 \pm 0.04 a$ \\
\hline G3 & $91.90 \pm 0.66 \mathrm{~g}$ & $87.74 \pm 0.09 b$ & $89.51 \pm 3.51 f$ & $90.40 \pm 2.06 a$ & $0.29 \pm 0.05 a$ \\
\hline G4 & $91.78 \pm 0.59 \mathrm{e}$ & $87.68 \pm 0.17 \mathrm{e}$ & $88.52 \pm 2.19 \mathrm{e}$ & $90.19 \pm 6.23 a$ & $0.54 \pm 0.04 a$ \\
\hline G5 & $91.69 \pm 0.45 d$ & $87.48 \pm 0.20 d$ & $86.76 \pm 0.34 d$ & $89.60 \pm 4.55 a$ & $0.28 \pm 0.05 a$ \\
\hline G6 & $91.81 \pm 0.44 f$ & $87.69 \pm 0.44 \mathrm{e}$ & $91.00 \pm 0.56 \mathrm{~g}$ & $88.20 \pm 0.32 a$ & $0.28 \pm 0.02 a$ \\
\hline
\end{tabular}

Table 9. Effect of phytase and groundnut meal on total phosphorus, phytate and available phosphorus composition

\begin{tabular}{|c|c|c|c|}
\hline Sources of variation, $P$ value & Total phosphorus (\%) & Phytate (\%) & Available phosphorus (\%) \\
\hline Phytase & 0.001 & 0.001 & 0.002 \\
\hline Groundnut & 0.000 & 0.000 & 0.000 \\
\hline Phytase* Groundnut & 0.000 & 0.000 & 0.000 \\
\hline Pooled SE & 0.004 & 0.003 & 0.002 \\
\hline \multicolumn{4}{|l|}{ Main effects } \\
\hline \multicolumn{4}{|l|}{ Phytase } \\
\hline PO & $0.94 \pm 0.17 d$ & $0.40 \pm 0.13 b$ & $0.54 \pm 0.20 d$ \\
\hline P1 & $0.90 \pm 0.08 c$ & $0.39 \pm 0.16 a$ & $0.51 \pm 0.18 c$ \\
\hline P2 & $0.88 \pm 0.08 b$ & $0.48 \pm 0.12 c$ & $0.40 \pm 0.12 b$ \\
\hline P3 & $0.89 \pm 0.07 b$ & $0.49 \pm 0.08 c$ & $0.40 \pm 0.13 b$ \\
\hline P4 & $0.85 \pm 0.12 a$ & $0.48 \pm 0.13 c$ & $0.37 \pm 0.21 \mathrm{a}$ \\
\hline \multicolumn{4}{|l|}{ Groundnut } \\
\hline G0 & $1.31 \pm 0.01 \mathrm{~g}$ & $0.40 \pm 0.02 a$ & $0.91 \pm 0.01 \mathrm{~g}$ \\
\hline G1 & $0.98 \pm 0.02 f$ & $0.43 \pm 0.19 b$ & $0.55 \pm 0.20 f$ \\
\hline G2 & $0.96 \pm 0.02 \mathrm{e}$ & $0.50 \pm 0.06 d$ & $0.46 \pm 0.04 d$ \\
\hline G3 & $0.90 \pm 0.01 d$ & $0.52 \pm 0.09 \mathrm{e}$ & $0.38 \pm 0.13 c$ \\
\hline G4 & $0.88 \pm 0.02 c$ & $0.39 \pm 0.09 a$ & $0.49 \pm 0.11 \mathrm{e}$ \\
\hline G5 & $0.84 \pm 0.03 b$ & $0.47 \pm 0.11 \mathrm{c}$ & $0.37 \pm 0.16 b$ \\
\hline G6 & $0.73 \pm 0.06 a$ & $0.40 \pm 0.17 a$ & $0.33 \pm 0.18 a$ \\
\hline
\end{tabular}


Table 10. Effect of soya bean and phytase on growth performance of juvenile Clarias gariepinus

\begin{tabular}{|c|c|c|c|c|c|c|c|c|c|}
\hline $\begin{array}{l}\text { Sources of } \\
\text { variation, } \\
P \text { value }\end{array}$ & $\begin{array}{l}\text { Mean initial } \\
\text { weight } \\
\text { (g/fish) }\end{array}$ & $\begin{array}{l}\text { Mean final } \\
\text { weight } \\
\text { (g/fish) }\end{array}$ & $\begin{array}{l}\text { Mean weight } \\
\text { gain (g/fish) }\end{array}$ & $\begin{array}{l}\text { Daily } \\
\text { weight gain } \\
\text { (g/fish/day) }\end{array}$ & $\begin{array}{l}\text { Mean feed } \\
\text { intake (g/fish) }\end{array}$ & FCR & $\begin{array}{l}\text { Protein } \\
\text { efficiency } \\
\text { ratio }\end{array}$ & $\mathrm{Ca} / \mathrm{P}$ & $\begin{array}{l}\text { Survival rate } \\
(\%)\end{array}$ \\
\hline Phytase & 0.24 & 0.02 & 0.007 & 0.000 & 0.016 & 0.000 & 0.007 & 0.000 & 0.079 \\
\hline Soya bean & 0.27 & 0.00 & 0.000 & 0.000 & 0.000 & 0.000 & 0.000 & 0.000 & 0.000 \\
\hline Phytase* & 0.24 & 0.02 & 0.001 & 0.095 & 0.078 & 0.000 & 0.001 & 0.000 & 0.094 \\
\hline $\begin{array}{l}\text { Soya bean } \\
\text { Pooled SE } \\
\text { Main effects } \\
\text { Phytase }\end{array}$ & 0.17 & 0.53 & 0.483 & 0.008 & 0.637 & 0.058 & 0.483 & 0.058 & 0.031 \\
\hline PO & $11.92 \pm 6.90$ & $42.94 \pm 16.46$ & $\begin{array}{l}31.07 \pm \\
16.49 \mathrm{bc}\end{array}$ & $0.38 \pm 0.21 a$ & $50.73 \pm 7.91 \mathrm{ab}$ & $4.48 \pm 6.47 \mathrm{c}$ & $1.36 \pm 0.65 b c$ & $1.40 \pm 0.12 a$ & $97.31 \pm 3.65 c$ \\
\hline P1 & $11.25 \pm 1.78$ & $43.38 \pm 12.34$ & $32.13 \pm 13.26 c$ & $0.46 \pm 0.19 b$ & $49.57 \pm 8.50 \mathrm{ab}$ & $1.85 \pm 0.91 \mathrm{a}$ & $1.59 \pm 0.47 c$ & $1.46 \pm 0.04 d$ & $91.35 \pm 0.42 b$ \\
\hline P2 & $11.82 \pm 1.09$ & $38.15 \pm 12.41$ & $26.33 \pm 12.18 a$ & $0.33 \pm 0.14 a$ & $46.13 \pm 9.60 a$ & $2.28 \pm 1.34 \mathrm{ab}$ & $1.35 \pm 0.55 a$ & $1.71 \pm 0.35 \mathrm{ab}$ & $91.35 \pm 12.29 b$ \\
\hline P3 & $12.56 \pm 1.22$ & $42.19 \pm 15.92$ & $29.82 \pm 15.40 a b c$ & $0.38 \pm 0.18 a$ & $53.98 \pm 11.35 b$ & $2.41 \pm 1.38 b$ & $\begin{array}{l}1.24 \pm \\
0.54 a b c\end{array}$ & $1.59 \pm 0.14 \mathrm{c}$ & $89.90 \pm 9.41 \mathrm{ab}$ \\
\hline P4 & $11.82 \pm 1.16$ & $39.09 \pm 14.30$ & $\begin{array}{l}15.40 \pm \\
27.27 a b\end{array}$ & $0.36 \pm 0.17 a$ & $50.16 \pm 10.33 a b$ & $2.51 \pm 1.60 b$ & $1.22 \pm 0.62 a b$ & $1.54 \pm 0.17 c$ & $84.47 \pm 18.29 a$ \\
\hline \multicolumn{10}{|l|}{ Soya bean } \\
\hline so & $11.89 \pm 0.55$ & $58.71 \pm 2.49$ & $46.90 \pm 1.83 d$ & $0.61 \pm 0.03 d$ & $60.54 \pm 3.26 c$ & $1.29 \pm 0.01 \mathrm{a}$ & $1.70 \pm 0.0 c$ & $1.41 \pm 0.00 \mathrm{ab}$ & $92.31 \pm 0.01 \mathrm{~b}$ \\
\hline S1 & $12.45 \pm 1.30$ & $52.21 \pm 3.24$ & $39.96 \pm 3.03 c$ & $0.49 \pm 0.05 c$ & $57.09 \pm 3.77 \mathrm{c}$ & $1.43 \pm 0.13 a$ & $1.65 \pm 0.13 c$ & $1.39 \pm 0.07 a$ & $97.31 \pm 3.17 b$ \\
\hline S2 & $11.30 \pm 0.90$ & $47.89 \pm 6.45$ & $36.59 \pm 5.25 c$ & $0.50 \pm 0.09 c$ & $49.08 \pm 5.51 b$ & $1.35 \pm 0.08 a$ & $1.80 \pm 0.16 c$ & $1.62 \pm 0.27 a$ & $93.85 \pm 4.87 \mathrm{~b}$ \\
\hline S3 & $11.89 \pm 1.64$ & $42.24 \pm 6.31$ & $30.35 \pm 7.23 b$ & $0.38 \pm 0.09 a$ & $54.99 \pm 7.07 \mathrm{bc}$ & $1.89 \pm 0.46 a$ & $1.34 \pm 0.35 \mathrm{ab}$ & $1.45 \pm 0.10 a$ & $96.15 \pm 3.14 b$ \\
\hline S4 & $11.87 \pm 0.84$ & $19.10 \pm 3.71$ & $7.23 \pm 3.53 a$ & $0.12 \pm 0.05 b$ & $37.34 \pm 4.38 a$ & $6.78 \pm 5.29 b$ & $0.48 \pm 0.22 b$ & $1.70 \pm 0.22 b$ & $77.19 \pm 15.39 a$ \\
\hline
\end{tabular}


Table 11. Effect of groundnut and phytase on growth performance of juvenile Clarias gariepinus

\begin{tabular}{|c|c|c|c|c|c|c|c|c|c|}
\hline $\begin{array}{l}\text { Sources of } \\
\text { variation, } \\
P \text { value } \\
\end{array}$ & $\begin{array}{l}\text { Mean initial } \\
\text { weight } \\
\text { (g/fish) }\end{array}$ & $\begin{array}{l}\text { Mean final } \\
\text { weight } \\
\text { (g/fish) }\end{array}$ & $\begin{array}{l}\text { Mean weight } \\
\text { gain (g/fish) }\end{array}$ & $\begin{array}{l}\text { Mean feed } \\
\text { intake } \\
\text { (g/fish/day) }\end{array}$ & FCR & $\begin{array}{l}\text { Specific growth } \\
\text { rate }(\%)\end{array}$ & $\begin{array}{l}\text { Daily weight } \\
\text { gain (g/fish) }\end{array}$ & $\mathrm{Ca} / \mathrm{P}$ ratio & $\begin{array}{l}\text { Survival rate } \\
(\%)\end{array}$ \\
\hline Phytase & 0.00 & 0.00 & 0.01 & 0.00 & 0.00 & 0.00 & 0.00 & 0.00 & 0.00 \\
\hline Groundnut & 0.00 & 0.00 & 0.000 & 0.00 & 0.00 & 0.00 & 0.00 & 0.00 & 0.00 \\
\hline $\begin{array}{l}\text { Phytase* } \\
\text { Groundnut }\end{array}$ & 0.00 & 0.00 & 0.001 & 0.00 & 0.00 & 0.00 & 0.00 & 0.00 & 0.00 \\
\hline $\begin{array}{l}\text { Pooled SE } \\
\text { Main effects } \\
\text { Phytase }\end{array}$ & 0.01 & 0.08 & 0.05 & 0.01 & 0.05 & 0.00 & 0.00 & 0.058 & 0.27 \\
\hline PO & $12.01 \pm 1.70$ & $38.18 \pm 12.29$ & $26.17 \pm 13.47 a$ & $41.85 \pm 9.15 c$ & $2.13 \pm 1.49 d$ & $1.14 \pm 0.45 a$ & $0.33 \pm 0.17 a$ & $2.62 \pm 1.3 e$ & $94.68 \pm 4.68 a b$ \\
\hline P1 & $11.53 \pm 0.60$ & $52.66 \pm 13.72$ & $41.13 \pm 13.94 \mathrm{e}$ & $44.22 \pm 5.30 \mathrm{~d}$ & $1.18 \pm 0.36 a$ & $1.56 \pm 0.33 \mathrm{e}$ & $0.51 \pm 0.18 c$ & $2.25 \pm 0.34 c$ & $96.79 \pm 2.22 b$ \\
\hline P2 & $11.54 \pm 1.09$ & $46.43 \pm 19.96$ & $34.89 \pm 20.43 d$ & $40.54 \pm 8.23 b$ & $2.48 \pm 8.31 \mathrm{e}$ & $1.32 \pm 0.72 c$ & $0.43 \pm 0.26 b$ & $2.07 \pm 0.14 a$ & $93.27 \pm 7.89 a$ \\
\hline P3 & $11.69 \pm 1.09$ & $45.54 \pm 7.56$ & $33.85 \pm 7.80 c$ & $40.64 \pm 3.85 b$ & $1.24 \pm 0.21 b$ & $1.41 \pm 0.21 \mathrm{~d}$ & $0.43 \pm 0.09 b$ & $2.15 \pm 0.46 b$ & $94.23 \pm 4.18 a$ \\
\hline $\mathrm{P} 4$ & $12.83 \pm 1.92$ & $39.36 \pm 12.01$ & $26.53 \pm 11.95 b$ & $38.52 \pm 4.78 a$ & $1.98 \pm 1.56 c$ & $1.19 \pm 0.39 b$ & $0.33 \pm 0.14 a$ & $2.43 \pm 0.15 d$ & $93.91 \pm 7.24 a$ \\
\hline \multicolumn{10}{|l|}{ Groundnut } \\
\hline $\mathrm{G} 0$ & $11.89 \pm 0.55$ & $58.71 \pm 2.49$ & $46.82 \pm 1.83 \mathrm{~g}$ & $60.54 \pm 3.26 \mathrm{e}$ & $1.29 \pm 0.01 d$ & $1.90 \pm 0.01 \mathrm{~g}$ & $0.61 \pm 0.02 a$ & $1.41 \pm 0.00 \mathrm{a}$ & $92.31 \pm 0.00 b$ \\
\hline G1 & $12.26 \pm 0.59$ & $55.48 \pm 5.65$ & $43.22 \pm 5.98 f$ & $45.10 \pm 2.00 d$ & $1.06 \pm 1.15 a$ & $1.60 \pm 0.15 f$ & $0.53 \pm 0.07 d$ & $2.44 \pm 0.02 d$ & $96.92 \pm 3.03 c$ \\
\hline G2 & $11.86 \pm 0.88$ & $52.89 \pm 14.55$ & $41.03 \pm 15.05 e$ & $44.28 \pm 5.09 d$ & $1.21 \pm 0.42 b$ & $1.54 \pm 0.38 \mathrm{e}$ & $0.52 \pm 0.19 d$ & $2.31 \pm 0.24 c$ & $95.00 \pm 3.17 \mathrm{bc}$ \\
\hline G3 & $11.99 \pm 0.64$ & $48.51 \pm 12.58$ & $36.52 \pm 12.37 d$ & $41.53 \pm 5.64 c$ & $1.25 \pm 0.36 c$ & $1.49 \pm 0.32 d$ & $0.45 \pm 0.16 c$ & $2.28 \pm 0.45 c$ & $96.92 \pm 2.43 c$ \\
\hline G4 & $11.43 \pm 15.57$ & $42.57 \pm 7.81$ & $28.14 \pm 8.05 b$ & $36.74 \pm 5.38 a$ & $1.36 \pm 0.28 f$ & $1.28 \pm 0.25 b$ & $0.35 \pm 0.11 b$ & $2.90 \pm 1.40 \mathrm{e}$ & $95.38 \pm 5.06 \mathrm{bc}$ \\
\hline G5 & $12.34 \pm 0.57$ & $42.42 \pm 11.25$ & $30.08 \pm 11.05 c$ & $37.21 \pm 6.26 a$ & $1.33 \pm 0.31 \mathrm{e}$ & $1.31 \pm 0.29 c$ & $0.37 \pm 0.13 b$ & $1.97 \pm 0.23 b$ & $96.54 \pm 2.84 c$ \\
\hline G6 & $12.06 \pm 1.00$ & $24.04 \pm 10.62$ & $11.98 \pm 10.62 a$ & $38.39 \pm 4.18 b$ & $2.06 \pm 0.35 \mathrm{~g}$ & $0.59 \pm 0.48 a$ & $0.16 \pm 0.13 a$ & $2.16 \pm 0.19 b c$ & $87.30 \pm 8.51 \mathrm{a}$ \\
\hline
\end{tabular}


Uzezi et al.; ARRB, 31(4): 1-21, 2019; Article no.ARRB.26092

Table 12. Effect of soya bean and phytase on dietary amino acid profile of juvenile Clarias gariepinus

\begin{tabular}{|c|c|c|c|c|c|c|c|c|c|}
\hline $\begin{array}{l}\text { Sources of variation, } \\
P \text { value }\end{array}$ & Lysine (\%) & Histidine (\%) & Arginine (\%) & Threonine (\%) & $\begin{array}{l}\text { Cysteine } \\
(\%)\end{array}$ & $\begin{array}{l}\text { Methionine } \\
(\%)\end{array}$ & $\begin{array}{l}\text { Isoleucine } \\
(\%)\end{array}$ & $\begin{array}{l}\text { Leucine } \\
(\%)\end{array}$ & $\begin{array}{l}\text { Phenylalanine } \\
(\%)\end{array}$ \\
\hline Phytase & 0.001 & 0.001 & 0.001 & 0.002 & 0.002 & 0.001 & 0.001 & 0.002 & 0.001 \\
\hline Soya bean & 0.000 & 0.011 & 0.002 & 0.010 & 0.001 & 0.001 & 0.002 & 0.000 & 0.001 \\
\hline Phytase* Soya bean & 0.003 & 0.005 & 0.001 & 0.003 & 0.001 & 0.000 & 0.001 & 0.003 & 0.001 \\
\hline \multicolumn{10}{|l|}{ Main effects } \\
\hline \multicolumn{10}{|l|}{ Phytase } \\
\hline $\mathrm{PO}$ & $4.72 \pm 0.66 a$ & $2.26 \pm 0.02 c$ & $6.35 \pm 1.48 \mathrm{e}$ & $2.92 \pm 0.47 a$ & $0.94 \pm 0.22 a$ & $2.04 \pm 0.21 d$ & $2.81 \pm 0.23 a$ & $7.35 \pm 0.56 e$ & $4.20 \pm 0.36 d$ \\
\hline P1 & $5.14 \pm 0.36 d$ & $2.25 \pm 0.12 d$ & $5.50 \pm 0.43 a$ & $3.33 \pm 0.22 \mathrm{e}$ & $1.03 \pm 0.18 c$ & $2.14 \pm 1.04 \mathrm{e}$ & $3.33 \pm 0.35 d$ & $6.60 \pm 0.33 d$ & $4.17 \pm 0.13 b$ \\
\hline P2 & $5.45 \pm 0.65 e$ & $2.38 \pm 0.16 e$ & $6.11 \pm 0.18 d$ & $3.02 \pm 0.77 b$ & $1.11 \pm 0.27 e$ & $1.36 \pm 0.60 a$ & $3.49 \pm 0.52 e$ & $6.18 \pm 1.45 b$ & $4.19 \pm 0.38 c$ \\
\hline P3 & $4.99 \pm 0.69 c$ & $2.24 \pm 0.09 a$ & $5.57 \pm 0.43 b$ & $3.04 \pm 0.13 c$ & $1.05 \pm 0.32 d$ & $1.61 \pm 0.58 b$ & $3.26 \pm 0.26 b$ & $6.34 \pm 2.01 \mathrm{a}$ & $4.07 \pm 0.07 a$ \\
\hline P4 & $4.97 \pm 0.69 b$ & $2.24 \pm 0.14 a$ & $5.61 \pm 0.60 c$ & $3.05 \pm 0.30 \mathrm{~d}$ & $1.02 \pm 0.34 b$ & $1.96 \pm 0.85 c$ & $3.27 \pm 0.50 c$ & $6.40 \pm 0.79 c$ & $4.24 \pm 0.62 e$ \\
\hline \multicolumn{10}{|l|}{ Soya bean } \\
\hline so & $5.24 \pm 0.02 c$ & $2.24 \pm 0.01 b$ & $4.83 \pm 0.01 a$ & $3.26 \pm 0.01 d$ & $0.79 \pm 0.02 a$ & $2.19 \pm 0.01 d$ & $2.44 \pm 0.01 \mathrm{a}$ & $7.32 \pm 0.01 \mathrm{e}$ & $3.88 \pm 0.02 b$ \\
\hline S1 & $5.61 \pm 0.28 d$ & $2.38 \pm 0.13 e$ & $5.55 \pm 0.41 c$ & $3.39 \pm 0.25 e$ & $0.95 \pm 0.18 c$ & $2.56 \pm 0.49 \mathrm{e}$ & $3.29 \pm 0.36 d$ & $6.97 \pm 0.78 d$ & $4.21 \pm 0.10 d$ \\
\hline S2 & $4.88 \pm 0.68 b$ & $2.14 \pm 0.14 a$ & $5.54 \pm 0.63 b$ & $2.70 \pm 0.50 a$ & $0.79 \pm 0.21 b$ & $2.05 \pm 0.84 c$ & $3.00 \pm 0.23 b$ & $5.68 \pm 1.13 a$ & $3.76 \pm 0.23 a$ \\
\hline S3 & $4.32 \pm 0.26 a$ & $2.26 \pm 0.04 c$ & $6.10 \pm 0.46 d$ & $2.97 \pm 0.36 b$ & $1.14 \pm 0.25 d$ & $1.28 \pm 0.30 a$ & $3.27 \pm 0.54 c$ & $5.90 \pm 1.99 b$ & $4.13 \pm 0.23 c$ \\
\hline S4 & $5.30 \pm 0.48 e$ & $2.27 \pm 0.08$ & $6.42 \pm 1.31 \mathrm{e}$ & $3.15 \pm 0.41 \mathrm{c}$ & $1.27 \pm 0.12 \mathrm{e}$ & $1.37 \pm 0.32 b$ & $3.43 \pm 0.39 \mathrm{e}$ & $6.95 \pm 0.41 c$ & $4.65 \pm 0.38 \mathrm{e}$ \\
\hline
\end{tabular}

*Means with the same superscript in the same column are not significant $(P>0.05)$ 
Uzezi et al.; ARRB, 31(4): 1-21, 2019; Article no.ARRB. 26092

Table 13. Effect of phytase and groundnut meal on dietary amino acid composition of juvenile Clarias gariepinus

\begin{tabular}{|c|c|c|c|c|c|c|c|c|c|}
\hline $\begin{array}{l}\text { Sources of } \\
\text { variation, } P \text { value }\end{array}$ & Lysine (\%) & $\begin{array}{l}\text { Histidine } \\
(\%)\end{array}$ & $\begin{array}{l}\text { Arginine } \\
(\%)\end{array}$ & $\begin{array}{l}\text { Threonine } \\
(\%)\end{array}$ & $\begin{array}{l}\text { Cysteine } \\
(\%)\end{array}$ & $\begin{array}{l}\text { Methionine } \\
(\%)\end{array}$ & $\begin{array}{l}\text { Isoleucine } \\
(\%)\end{array}$ & Leucine (\%) & $\begin{array}{l}\text { Phenylalanine } \\
(\%)\end{array}$ \\
\hline Phytase & 0.001 & 0.001 & 0.001 & 0.002 & 0.002 & 0.000 & 0.001 & 0.002 & 0.001 \\
\hline Groundnut & 0.000 & 0.011 & 0.002 & 0.010 & 0.001 & 0.000 & 0.000 & 0.001 & 0.001 \\
\hline $\begin{array}{l}\text { Phytase* } \\
\text { Groundnut }\end{array}$ & 0.003 & 0.005 & 0.001 & 0.003 & 0.001 & 0.003 & 0.001 & 0.001 & 0.000 \\
\hline $\begin{array}{l}\text { Pooled SE } \\
\text { Main effects } \\
\text { Phytase }\end{array}$ & 0.003 & 0.003 & 0.002 & 0.002 & 0.002 & 0.001 & 0.002 & 0.002 & 0.002 \\
\hline PO & $\begin{array}{l}4.19 \pm \\
0.55 \mathrm{e}\end{array}$ & $2.20 \pm 0.08 e$ & $6.59 \pm 1.00 c$ & $3.02 \pm 0.19 d$ & $1.06 \pm 0.16 c$ & $2.23 \pm 0.04 \mathrm{e}$ & $2.86 \pm 0.25 c$ & $6.51 \pm 0.66 d$ & $4.04 \pm 0.36 d$ \\
\hline $\mathrm{P} 1$ & $4.17 \pm 0.51 d$ & $2.22 \pm 0.04 d$ & $7.14 \pm 0.90 \mathrm{e}$ & $3.05 \pm 0.17 e$ & $1.20 \pm 0.11 \mathrm{e}$ & $2.22 \pm 0.02 d$ & $3.13 \pm 0.26 e$ & $6.63 \pm 0.43 e$ & $4.29 \pm 0.52 e$ \\
\hline $\mathrm{P} 2$ & $\begin{array}{l}3.84 \pm \\
0.44 c\end{array}$ & $2.21 \pm 0.06 c$ & $6.81 \pm 0.46 d$ & $2.89 \pm 0.25 \mathrm{c}$ & $1.08 \pm 0.15 d$ & $2.18 \pm 0.17 \mathrm{c}$ & $2.91 \pm 0.15 d$ & $6.18 \pm 0.52 c$ & $3.90 \pm 0.39 c$ \\
\hline P3 & $\begin{array}{l}3.84 \pm \\
0.44 b\end{array}$ & $2.19 \pm 0.09 a$ & $6.40 \pm 1.06 a$ & $2.70 \pm 0.37 a$ & $0.97 \pm 0.17 a$ & $2.16 \pm 0.10 a$ & $2.78 \pm 0.40 b$ & $5.31 \pm 1.22 a$ & $3.56 \pm 0.43 a$ \\
\hline P4 & $\begin{array}{l}3.74 \pm \\
0.78 a\end{array}$ & $2.21 \pm 0.05 d$ & $6.58 \pm 1.22 b$ & $2.83 \pm 0.31 \mathrm{~b}$ & $1.00 \pm 1.00 \mathrm{~b}$ & $2.18 \pm 0.08 b$ & $2.69 \pm 0.34 a$ & $6.07 \pm 0.55 b$ & $3.84 \pm 0.64 b$ \\
\hline \multicolumn{10}{|l|}{$\begin{array}{l}\text { Groundnut } \\
\text { (roasted) }\end{array}$} \\
\hline G0 & $5.24 \pm 0.02 \mathrm{~g}$ & $2.24 \pm 0.01 \mathrm{e}$ & $4.83 \pm 0.01 \mathrm{a}$ & $3.26 \pm 0.24 \mathrm{~g}$ & $0.79 \pm 0.02 a$ & $2.19 \pm 0.01 \mathrm{c}$ & $2.44 \pm 0.01 a$ & $7.32 \pm 0.00 \mathrm{~g}$ & $3.88 \pm 0.02 e$ \\
\hline G1 & $3.87 \pm 0.53 d$ & $2.22 \pm 0.07 \mathrm{c}$ & $6.47 \pm 0.91 d$ & $2.87 \pm 0.24 \mathrm{~d}$ & $1.09 \pm 0.15 d$ & $2.22 \pm 0.03 g$ & $2.86 \pm 0.39 d$ & $6.56 \pm 0.46 \mathrm{e}$ & $3.85 \pm 0.34 d$ \\
\hline G2 & $3.98 \pm 0.28 \mathrm{e}$ & $2.16 \pm 0.09 a$ & $6.30 \pm 0.47 c$ & $2.99 \pm 0.27 \mathrm{e}$ & $1.00 \pm 0.21 b$ & $2.20 \pm 0.06 \mathrm{e}$ & $2.87 \pm 0.38 \mathrm{e}$ & $5.99 \pm 0.63 c$ & $4.14 \pm 0.46 f$ \\
\hline G3 & $3.74 \pm 0.36 b$ & $2.17 \pm 0.08 b$ & $6.59 \pm 0.55 \mathrm{e}$ & $3.16 \pm 0.16 f$ & $1.08 \pm 0.17 \mathrm{c}$ & $2.20 \pm 0.07 f$ & $2.99 \pm 0.26 f$ & $6.14 \pm 0.59 d$ & $3.82 \pm 0.48 \mathrm{c}$ \\
\hline G4 & $3.55 \pm 0.31 a$ & $2.22 \pm 0.04 \mathrm{c}$ & $6.01 \pm 0.69 b$ & $2.73 \pm 0.31 a$ & $1.00 \pm 0.17 \mathrm{c}$ & $2.19 \pm 0.06 b$ & $2.78 \pm 0.17 \mathrm{~b}$ & $5.59 \pm 0.61 a$ & $3.52 \pm 0.27 a$ \\
\hline G5 & $3.80 \pm 0.58 c$ & $2.23 \pm 0.03 d$ & $7.22 \pm 0.64 f$ & $2.82 \pm 0.21 \mathrm{c}$ & $1.08 \pm 0.17 b$ & $2.22 \pm 0.05 d$ & $3.06 \pm 0.31 \mathrm{~g}$ & $5.78 \pm 1.51 b$ & $3.73 \pm 0.55 b$ \\
\hline G6 & $4.59 \pm 0.48 f$ & $2.22 \pm 0.04 \mathrm{c}$ & $7.98 \pm 0.67 \mathrm{~g}$ & $2.81 \pm 0.36 \mathrm{~b}$ & $1.19 \pm 0.15 \mathrm{e}$ & $2.15 \pm 0.13 a$ & $2.78 \pm 0.29 c$ & $6.62 \pm 0.34 f$ & $4.49 \pm 0.51 \mathrm{~g}$ \\
\hline
\end{tabular}

${ }^{*}$ Means with the same superscript in the same column are not significant $(P>0.05)$ 


\section{CONCLUSION}

The research has shown that the significant reduction in phytate phosphorus and an improvement in available phosphorus, amino acids profile and growth performance of fish were achieved at the lowest level of phytase (250 FTU/g) in both diets, with an available phosphorus of between $0.75 \%$ and $0.80 \%$ (quadratic regression), which may indicate that the chemical nature and structure of phytate, rather than the concentration and location, as well as stomach $\mathrm{pH}$ of Clarias gariepinus, may influence phosphorus utilization, and hence, optimum growth response to phytase. However, several processing methods of reducing the fat levels in fish diets without reducing phytate concentration should be explored to reduce possible impact on phosphorus utilization by phytase.

\section{ETHICAL APPROVAL}

The experimental protocols and procedures used in this study were approved by the Ethical committee, University of Ibadan, Ibadan, Nigeria and conform to the guideline of the care and use of animals in research and teaching $(\mathrm{NIH}$ publications no 85-93, revised 1985).

\section{COMPETING INTERESTS}

Authors have declared that no competing interests exist.

\section{REFERENCES}

1. Selle PH, Ravindran V. Microbial phytase in poultry nutrition. Anim. Feed Sci. Technol. 2007;135:1-41.

2. Singh PK. Significance of phytic acid and supplemental phytase in chicken nutrition: A review. World Poultry Science Journal. 2008;64:553-580.

3. Kumar V, Sinha AK, Makkar HPS, Becker $\mathrm{K}$. Dietary roles of phytate and phytase in human nutrition: A review. Food Chemistry. 2010;120:945-959.

4. Onyango EM, Asem EK, Adeola O. Phytic acid increases mucin and endogenous amino acid losses from the gastrointestinal tract of chickens. British Journal of Nutrition. 2009;101:836-842

5. Kumar V, Sinha AK, Makkar HPS, De Boeck G, Becker K. Phytate and phytase in fish nutrition. J. Anim. Physiol. Anim. Nutr. 2011;96:335-364.

6. Ravindran V, Cabahug S, Ravindran G, Selle PH, Bryden WL. Response of broiler chickens to microbial phytase supplementation as influenced by dietary phytic acid and non-phytate phosphorus levels. II. Effects on apparent metabolisable energy, nutrient digestibility and nutrient retention. Br. Poult. Sci. 2000; 41:193-200.

7. Ravindran V, Selle $\mathrm{PH}$, Ravindran G, Morel, PCH, Kies AK, Bryden WL. Microbial phytase improves performance, apparent metabolisable energy and ileal amino acid digestibility of broilers fed a lysine-deficient diet. Poult. Sci. 2001;80: 338-344.

8. Cao L, Wang W, Yang C, Yang Y, Diana J, Yakupitiyage A, Luoand Z, Li D. Application of microbial phytase in fish feed. Enz.Microb. Technol. 2007;14:342362

9. Yu FN, Wang DZ. The effects of supplemental phytase on growth and the utilization of phosphorus by crucian carp Carassius carassius. J Fish Sci. Chin. 2000;7(2):106-9 [in Chinese].

10. Kornegay ET, Zhang Z, Denbow DM. Influence of microbial phytase supplementation of a low protein/ amino acid diet on performance, ileal digestibility of protein and amino acids, and carcass measurements of finishing broilers. In: Phytase in Animal Nutrition and Waste Management, second revised ed. BASF Corporation, Mount Olive, NJ.1999;557572.

11. Biehl RR, Baker DH. Efficacy of supplemental 1a-hydroxycholecalciferol and microbial phytase for young pigs fed phosphorus- or amino acid-deficient cornsoybean meal diets. J. Anim. Sci. 1996; 74:2960-2966.

12. Biehl RR, Baker DH. Microbial phytase improves amino acid utilization in young chicks fed diets based on soybean meal but not diets based on peanut meal. Poult Sci. 1997;76:355-360.

13. Kornegay ET, Denbow DM, Yi Z, Ravindran V. Response of broilers to graded levels of microbial phytase added to maize-soyabean meal-based-diets containing three levels of non-phytate phosphorus. Br. J. Nutr. 1996;75:839852. 
14. Zhang X, Kornegay ET, Roland DA, Mc Daniel GR, Rao SK. Effect of Natuphos ${ }^{\circledR}$ phytase supplementation to feed on performance and ileal digestibility of protein and amino acids in broilers. Poultry Science. 1999;78:1567-1572.

15. Huynh HPV, Nugegoda, D. Effects of Dietary Supplements on Growth Performance and Phosphorus Waste Production of Australian Catfish, Tandanus tandanus, Fed with Diets Containing Canola Meal as Fishmeal Replacement. Aqua, Res. Dev. 2012;2:4.

Available:http://dx.doi.org/10.4172/21559546.1000117

16. Nwanna LC, Adebayo IA, Omitoyin BO. Phosphorus requirements of African catfish, Clarias gariepinus, based on broken-line regression analysis methods. Science Asia. 2009;35:227-233.

17. Van Weerd $\mathrm{JH}$, Khalaf $\mathrm{KH}$, Aartsen $\mathrm{EJ}$, Tijssen PA. Balance trials with African catfish Clarias gariepinus fed phytasetreated soybean meal-baseddiets. Aquaculture Nutrition. 1999;5:135-42.

18. Nwanna LC, Ajani EK, Bamidele F. Determination of optimum dietary phytase level for the growth and mineral deposition in African catfish (Clarias gariepinus). Agricultural Science. 2006;54(1):75-82.

19. Ajani EK, Akinwole AO, Ayodele IA. Fundamentals of fish farming in Nigeria. 2011;158

20. Erdman JW. Jr. Oilseed phytates: Nutritional implications. J. Am. Oil. Chem. Soc. 1979;56:736-741.

21. Maga JA. Phytate: Its chemistry, occurrence, food interactions, nutritional significance and methods of analysis. J. Agric. Food Chem. 1982;30:1-9.

22. Akpoilih BU, Ajani EK, Omitoyin BO. Optimum dietary $\mathrm{Ca} / \mathrm{P}$ ratio for growth and bone mineralization in juvenile Clarias gariepinus fed soya bean-based diets. J Aquac Res Development. 2016a;7:403. DOI:10.4172/2155-9546.1000403

23. Nwanna LC. Effects of toasting and incubation on soya bean meal supplemented with phytase in practical diet of Nile tilapia. Journal of Animal and Veterinary advances. 2005;4(2):234-239.

24. Cao L, Yang Y, Wang WM, Yakupitiyage A, Yuan DR, Diana JS. Effects of pretreatment with microbial phytase on phosphorous utilization and growth performance of Nile tilapia (Oreochromis niloticus). Aquaculture Nutrition; 2008.
DOI: 10.1111/j.1365-2095.2007.00508.x

25. Pearson D. The chemical analysis of foods. 7th Edition, Churchill Livingstone, London; 1976.

26. Akpoilih BU. Serum biochemistry, body composition and bone mineralization of juvenile Clarias gariepinus fed phytasesupplemented soya bean-based diets. Journal of Aquatic Sciences. 2015;30(2): 407-425.

27. National Research Counçil (NRC). Nutrient requirements of Fish, National Academy Press, Washington, DC. 1993;114.

28. Association of official Analytical Chemists (AOAC). Official Methods of Analysis, 15th edn, Association of Official Analytical Chemists, Washington, DC, USA. 1990; 1230.

29. Association of Official Analytical Chemists. Official Method of Analysis of the AOAC. Horwitz W (Ed) Eighteenth Edition. Washighton D.C, AOAC. Gaithersburg: ASA-SSA Inc. 2006;30-31.

30. Akpoilih BU, Ajani EK, Omitoyin BO. Dietary Phytase Improves Growth and Water Quality Parameters for Juvenile Clarias gariepinus Fed Soya bean Mealbased Diets. International Journal of Aquaculture. 2015;5(41):1-20

DOI: 10.5376/ija.2015.05.0041

31. Engelen AJ, van der Heeft FC, Randsdorp PHG, Smith ELC. Simple and rapid determination of phytase activity. J. AOAC Int. 1994;77:760-764.

32. Benitez LV. Amino Acid and fatty acid profiles in aquaculture nutrition studies, $p$. 23-35. In: De Silva SS (ed.) Fish Nutrition Research in Asia. Proceedings of the Third Asian Fish Nutrition Network Meeting. Asian fish. Society Special Publication 4. Asian Fisheries Society, Manila Philippines. 1989;166.

33. Gomez MGU, López-Aceves LA, PoncePalafox JT, Rodríguez-González $H$, Arredondo-Figueroa JL. Growth of freshwater prawn Macrobrachium tenellum (Smith, 1871) juveniles fed isoproteic diets substituting fish meal by soya bean meal. 2008;51(1):57-65.

34. Hossain MA, Almatar, SM, James, CM. Effect of Varying Dietary Lipid Levels and Protein to Energy (P:E) Ratios on Growth Performance, Feed Utilization and Body Composition of Sub-adult Silver Pomfrets, Pampus argenteus (Euphrasen,1788). Pakistan Journal of Nutrition. 2011;10(5): 415-42. 
35. Adewolu MA, Benfey TJ. Growth, nutrient utilization and body composition of juvenile bagrid catfish, Chrysichthys nigrodigitatus (Actinopterygii: siluriformes: claroteidae), Fed different dietary crude protein levels. acta ichthyologica et piscatorial. 2009;39 (2):95-101.

36. Nwanna LC, Kolahsa M, Eisenreich R, Schwarz FJ. Pre-treatment of dietary plant feedstuffs with phytase and its effect on growth and mineral concentration in common carp (Cyprinus carpio L.). Journal of Animal Physiology and Animal Nutrition. 2008;92:677-682.

37. Singh $\mathrm{P}$, Maqsood S, Samoon MH, Phulia V, Danish M, Chalal RS. Exogenous supplementation of papain as growth promoter in diet of fingerlings of Cyprinus carpio. Int Aquat Res. 2011;3:1-9.

38. Nwanna LC. Effect of Dietary phytase on Growth, Enzyme Activities and Phosphorus Load of Nile Tilapia (Oreochromis niloticus). Journal of Engineering and Applied Sciences. 2007; 2:972-976.

39. Sajjadi M, Carter CG. Effect of phytic acid and phytase on feed intake, growth, digestibility and trypsin activity in Atlantic salmon (Salmo salar L.). Aquacult Nutr. 2004;10(2):135-42.

40. AFMA Matrix (2013). Quarterly magazine of the animal feed manufacturers. 2013; 23:3

41. Nwanna LC, Schwarz FJ. Effect of supplemental phytase on growth, phosphorus digestibility and bone mineralization of common carp (Cyprinus carpio L). Aquaculture Research. 2007;38: 1037-1044.

42. Hussain SM, Afzal M, Rana SA, Javid A, lqbal $M$. Effect of Phytase Supplementation on Growth Performance and Nutrient Digestibility of Labeo rohita Fingerlings Fed on Corn Gluten Mealbased Diets. Int. J. Agric. Biol. 2011a;13: 916-922.

43. Nwanna LC, Olusola SE. Effect of supplemental phytase on phosphorus digestibility and mineral composition of Nile tilapia (Oreochromis niloticus). International Journal of Aquaculture. 2014; 4(15):89-95.

44. Pham MA, Lee K-J, Dang TM, Lim S-J, Ko G-Y, Eo J, Oh D-H. Improved apparent digestibility coefficient of protein and phosphorus by supplementation of microbial phytase in diets containing cottonseed and soybean meal for juvenile olive flounder (Paralichthys olivaceus). Asian-Aust. J. Anim. Sci. 2008;21(9):1367 $-1375$.

45. Olukosi OA. Biochemistry of phytate and phytases: Applications in monogastric nutrition. Biokemistri. 2012;24(2):5863.

46. Juanpere J, Perez-Vendrell AM, Angulo E, Brufau J. Assessment of potential interactions between phytase and glycosidase enzyme supplementation on nutrient digestibility in broilers. Poult Sci. 2005;84:571-580.

47. Camden BJ, Morel PCH, Thomas DV, Ravindran V, Bedford MR. Effectiveness of exogenous microbial phytase in improving the bioavailabilities of phosphorus and other nutrients in maize-soya-bean meal diets for broilers. Anim. Sci. 2001;73:289297.

48. Li P, Mai K, Trushenski J, Wu G. New developments in fish amino acid nutrition: towards functional and environmentally oriented aqua feeds. Amino Acids; 2008. DOI: 10.1007/s00726-008-0171.

49. Zhou Q-C, Tan B-P, Mai K-S, Liu Y-J. Apparent digestibility of selected feedstuff for juvenile Cobia (Rachycentron canadum). Aquaculture. 2004;241:441451.

50. Hussain SM, Afzal M, Rana SA, Javid A, Hussain M. Impact of phytase supplementation on nutrient digestibility for Labeo rohita fingerlings fed on sunflower meal based diets. Pal. J. Life. Soc. Sci. 2011b;9(2):85-90.

51. Akpoilih BU, Omitoyin BO, Ajani EK. Effect of microbial phytase on phosphorus availability and growth of juvenile Clarias gariepinus fed differently processed soya bean diets. Journal of Aquatic Sciences. 2016b;31(1A):21-37.

52. Babalola TOO, Apata DF. Chemical and quality evaluation of some alternative lipid sources for aqua feed production. Agric. Biol. J. N. Am. 2008;2(6):935-943.

53. Chiba LI. Bone and vitamins/minerals. In: Nonruminant Nutrition Handbook. 2004; Section 7:194-238.

54. Rezq AA, Labib FA, Attia, AEM. Effect of some dietary oils and fats on serum lipid profile, calcium absorption and bone mineralization in mice. Pakistan Journal of Nutrition. 2010;9(7):643-650.

55. Raina R, Garg G, Sethi SK, Schreiber MJ, Simon JF, Thomas G. Phosphorus 
Metabolism. J Nephrol Therapeutic. 2012; S3:008.

DOI:10.4172/2161-0959. S3-008.

56. Ravindran V, Cabahug S, Ravindran G., Bryden WL. Influence of microbial phytase on apparent ileal amino acid digestibility in feedstuffs for broilers. Poultry Science. 1999;78:699-706.

57. Agbo NW. Oilseed Meals as Dietary Protein Sources for Juvenile Nile Tilapia (Oreochromis niloticus L.). PhD thesis, Institute of Aquaculture, University of Stirling, Scotland, UK. 2008;224.

58. Riche M, Trottier NL, Ku P K, Garling DL. Apparent digestibility of crude protein and apparent availability of individual amino acids in tilapia (Oreochromis niloticus) fed phytase pretreated soybean meal diets. Fish Physiology and Biochemistry. 2001; 25:181-194.

59. Haghbayan S, Mehrgan MS. The Effect of Replacing Fish Meal in the Diet with Enzyme-Treated Soybean Meal (HP310) on Growth and Body Composition of Rainbow Trout Fry. Molecules. 2015;20: 21058-21066.

60. Yu H-R, Zhang Q, Xiang D-M, Huang G-Q, Li W-Z, Liu S-W. Dietary available phosphorus requirement of walking catfish (Clarias leather). Aqua. Nutr. 2013;19(4): 483-490.

61. Qian H, Kornegay ET, Conner DE. Adverse effects of wide calcium: phosphorus ratios on supplemental phytase efficacy for weaning pigs fed two dietary phosphorus levels. J. Anim. Sci.1996;74:1288-1297.

62. Sebastian S, Touch burn SP, Chavez ER. Implications of Phytic acid and supplemented microbial phytase in poultry nutrition: a review. World's Poultry Science Journal. 1998;54:27-47

63. Hussain SM, Afzal M, Nasir S, Jabeen F, Javid A, Asrar M, Azmat H, Hussain M, Zakir S, Shah H, Arsala MZU. Effect of phytase supplementation on growth performance and mineral digestibility in Labeo rohita (Hamilton, 1822) fingerlings fed on sunflower meal based diet. Indian $\mathrm{J}$. Fish. 2015;62(4):71-79.

64. Hussain SM, Afzal M, Qadir SMM, Javid A, Hussain M, Nasir S, Shah SZH. Efficacy of phytase supplementation in improving mineral digestibility for Labeo rohita fingerlings fed on canola meal based diets. Iranian J. of Fish. Sci. 2014;15(2):645-661.

65. Robinson $\mathrm{EH}, \mathrm{Li} \mathrm{MH}$, Manning $\mathrm{BB}$. Comparison of microbial phytase and dicalcium phosphate for growth and bone mineralization of pond-raised channel catfish, Ictalurus punctatus. J Appl Aquacult. 2002;12:81-8.

66. Eeckhout W, De Paepe M. Total phosphorus, phytate phosphorus and phytase activity in plant feedstuffs. Animal Feed Science and Technology. 1994;47: 19-29.

67. Debnath D, Pal AK, Sahu NP, Jain KK, Yengkokpam S, Mukherjee SC. Effect of dietary microbial phytase supplementation on growth and nutrient digestibility of Pangasius pangasius (Hamilton) fingerlings. Aquaculture Research. 2005; 36:180-187.

68. Harland BF, Oberleas D. Phytate and Phytase in zinc homeostasis. In: Proceedings of the 1st International Phytase Summit. 28th-30th, August, 2010.Washington, D.C, USA. 2010;200.

69. Maenz DD, Engele-Schaan, CM, Newkirk RW, Classen HL. The effect of minerals and mineral chelators on the formation of phytase-resistant and phytase-susceptible forms of phytic acid in solution and in a slurry of canola meal. Anim. Feed Sci. Tech. 1999;81:177-192.

70. Geay F, Ferraresso S, Zambonino-Infante JL, Bargelloni L, Quentel C, Vandeputte M, Kaushik S, Cahu CL, Mazurais D. Effects of the total replacement of fish-based diet with plant-based diet on the hepatic transcriptome of two European sea bass (Dicentrarchus labrax) half-sibfamilies showing different growth rates with the plant-based diet. Genomics. 2011;12: 522.

(c) 2019 Uzezi et al.; This is an Open Access article distributed under the terms of the Creative Commons Attribution License (http://creativecommons.org/licenses/by/4.0), which permits unrestricted use, distribution, and reproduction in any medium, provided the original work is properly cited.

Peer-review history:

The peer review history for this paper can be accessed here: http://www.sdiarticle3.com/review-history/26092 